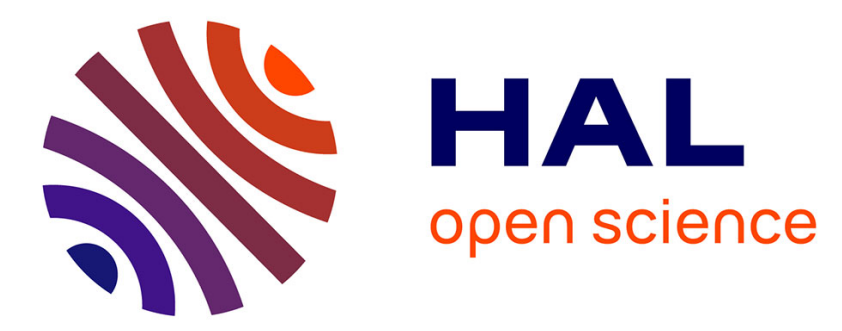

\title{
Delimiting species of marine gastropods (Turridae, Conoidea) using RAD sequencing in an integrative taxonomy framework
}

Jawad Abdelkrim, Laetitia Aznar-Cormano, Barbara Buge, Alexander Fedosov, Yuri I Kantor, Paul Zaharias, Nicolas Puillandre

\section{To cite this version:}

Jawad Abdelkrim, Laetitia Aznar-Cormano, Barbara Buge, Alexander Fedosov, Yuri I Kantor, et al.. Delimiting species of marine gastropods (Turridae, Conoidea) using RAD sequencing in an integrative taxonomy framework. Molecular Ecology, 2018, 27 (22), pp.4591-4611. hal-02002422

\section{HAL Id: hal-02002422 \\ https://hal.science/hal-02002422}

Submitted on 31 Jan 2019

HAL is a multi-disciplinary open access archive for the deposit and dissemination of scientific research documents, whether they are published or not. The documents may come from teaching and research institutions in France or abroad, or from public or private research centers.
L'archive ouverte pluridisciplinaire HAL, est destinée au dépôt et à la diffusion de documents scientifiques de niveau recherche, publiés ou non, émanant des établissements d'enseignement et de recherche français ou étrangers, des laboratoires publics ou privés. 
1 Delimiting species of marine gastropods (Turridae, Conoidea) using RAD-sequencing in

2

3

4

5

6 Abdelkrim J. ${ }^{1,4}$, Aznar-Cormano L. ${ }^{1}$, Buge B. ${ }^{2}$, Fedosov A. ${ }^{3}$, Kantor Y. ${ }^{3}$, Zaharias P. ${ }^{1}$,

$7 \quad$ Puillandre N..$^{1 *}$

8

$9 \quad 1$. Institut de Systématique Evolution Biodiversité (ISYEB), Muséum national d'Histoire

\section{an integrative taxonomy framework}

Running title: Species delimitation with RAD-seq naturelle, CNRS, Sorbonne Université, EPHE, 57 rue Cuvier, CP 26, 75005 Paris, France.

2. Muséum National d’Histoire Naturelle, Direction des Collections, 55, rue Buffon, 75005 Paris, France

${ }^{3}$. A.N. Severtsov Institute of Ecology and Evolution, Russian Academy of Sciences, Leninsky prospect 33, Moscow 119071, Russia

${ }^{4}$. Service de Systématique Moléculaire SSM- UMS2700 - Muséum national d’Histoire naturelle, 57 rue Cuvier, CP26, F-75005, Paris, France

* Corresponding author: puillandre@mnhn.fr

ZooBank registration: urn:lsid:zoobank.org:pub:0321C92D-53BD-4A97-9F1867A4A577A59A 


\section{ABSTRACT}

Species delimitation in poorly-known and diverse taxa is usually performed based on monolocus, DNA barcoding-like approaches, while multilocus data are often used to test alternative species hypotheses in well-studied groups. We combined both approaches to delimit species in the Xenuroturris / Iotyrris complex, a group of venomous marine gastropods from the Indo-Pacific. First, COI sequences were analyzed using three methods of species delimitation to propose primary species hypotheses. Second, RAD-sequencing data were also obtained and a maximum likelihood phylogenetic tree produced. We tested the impact of the level of missing data on the robustness of the phylogenetic tree obtained with the RAD-seq data. Alternative species partitions revealed with the COI dataset were also tested using the RAD-seq data and the Bayes Factor species delimitation method. The congruence between the species hypotheses proposed with the mitochondrial nuclear datasets, together with the morphological variability of the shell and the radula and the distribution pattern, was used to turn the primary species hypotheses into secondary species hypotheses. Allopatric primary species hypotheses defined with the COI gene were interpreted to correspond to intraspecific structure. Most of the species are found sympatrically in the Philippines, and only one is confidently identified as a new species and described as Iotyrris conotaxis n. sp. The results obtained demonstrate the efficiency of the combined monolocus/multilocus approach to delimit species.

Keywords: Species delimitation, integrative taxonomy, DNA barcoding, RAD-seq, Turridae. 


\section{INTRODUCTION}

The last decade has seen a burst of methods available to propose species hypotheses based on molecular data (Carstens, Pelletier, Reid, \& Satler, 2013; Ence \& Carstens, 2011; Fujisawa \& Barraclough, 2013; Leaché, Fujita, Minin, \& Bouckaert, 2014; Leavitt, Moreau, \& Lumbsch, 2015; N. Puillandre, Lambert, Brouillet, \& Achaz, 2012; Yang \& Rannala, 2014; Zhang, Kapli, Pavlidis, \& Stamatakis, 2013). Genetic data collection for species delimitation can be separated into two general approaches: (1) DNA barcoding, in which a high number of species/specimens are sequenced for one or a few markers, and (2) deep analyses of species complexes, where a limited number of species/specimens are analyzed with larger genetic datasets (ranging from 5-6 markers to several thousand markers). These two approaches lend themselves to particular classes of methods. For example, species delimitation methods based on monolocus data, such as GMYC (General Mixed-Yule-Coalescent method; Fujisawa \& Barraclough, 2013; Monaghan et al., 2009; Pons et al., 2006), PTP (Poisson-Tree Process; Zhang et al., 2013) or ABGD (Automatic Barcode Gap Discovery; Puillandre, Lambert, Brouillet, \& Achaz, 2012) are typically applied to taxa with no or limited genomic data available (i.e. understudied and/or hyperdiverse groups). For such groups, sequencing many markers for many specimens and species can be problematic. For example, there may be financial constraints that limit genetic sequencing (but see e.g. Coissac, Hollingsworth, Lavergne, \& Taberlet, 2016), but also because the lack of genomic information makes the identification of suitable markers for the species level difficult (but see e.g. Rutschmann, Detering, Simon, Fredslund, \& Monaghan, 2017). Here, DNA barcoding-like data can be used as a starting point to propose primary species hypotheses, in groups where such hypotheses do not exist or are highly questionable. Conversely, species delimitation methods based on multilocus data, such as SPEDESTEM (SPEcies Delimitation Using the Species Tree 
Estimation Method), BPP (Bayesian Phylogenetics and Phylogeography) or BFD (Bayes Factor Delimitation) (Ence \& Carstens, 2011; Leaché, Fujita, Minin, \& Bouckaert, 2014; Yang \& Rannala, 2014) are used to test alternative models of species delimitation. These methods are, generally, used for recently diverged lineages for which the speciation process may or may not be completely finalized (the "grey zone” - de Queiroz, 2007). Finally, the dichotomy between genetic sampling approaches can also be thought of in divergence times. For example, DNA barcoding approaches are better suited for systems containing old lineages, where genotypes and phenotypes are distinct and have become fixed between lineages. In contrast, more recent lineages will suffer from contradictions between gene trees and species trees because not enough time has passed for lineages to completely sort. These systems will require finer methods based on population genetics concepts (Pante et al., 2015b).

RAD-sequencing (Restriction site Associated DNA markers) is one relatively new approach that can be used to overcome the problem of colleting large multilocus genetic datasets in groups with traditionally poor genetic resources (Baird et al., 2008; Miller, Dunham, Amores, Cresko, \& Johnson, 2006), have been applied (Boucher, Casazza, Szövényi, \& Conti, 2016; Herrera \& Shank, 2016; Pante, Abdelkrim, et al., 2015). Here, we use a combination of DNAbarcoding-like approaches and RAD-seq data to delimit species. We initially apply DNA barcoding to define primary hypotheses of species delimitation, and use RAD-seq data to verify and test the species hypotheses, in a poorly-known group of marine gastropods, the Xenuroturris / Iotyrris complex. These species belong to the family Turridae, superfamily Conoidea, a hyperdiverse group of marine gastropods which developed a powerful venom apparatus to produce highly potent toxins used to capture their prey. The "turrids” are famous among malacologists for their highly variable shells, and this variability does not always 
coincide with species boundaries estimated using genetic data (e.g. Fedosov, Stahlschmidt, Puillandre, Aznar-Cormano, \& Bouchet, 2017; Puillandre, Cruaud, \& Kantor, 2010;

Puillandre, Sysoev, Olivera, Couloux, \& Bouchet, 2010; Puillandre, Fedosov, Zaharias, Aznar-Cormano, \& Kantor, 2017). Several hypotheses (retention of ancestral polymorphism, convergence, phenotypic plasticity) have been proposed to explain how highly similar shells can actually correspond to species that diverged more than 60MYA or, conversely, how morphological variation among populations within species can exceed variation estimated at the species level (Duda, Bolin, Meyer, \& Kohn, 2008; Puillandre et al., 2011; Puillandre, Baylac, Boisselier, Cruaud, \& Samadi, 2009). In the Xenuroturris / Iotyrris complex, Kantor, Puillandre, Olivera, \& Bouchet (2008) found that species with almost identical shells were easily distinguished with two genetic markers (COI - Cytochrome c Oxidase subunit I - and 28S) and by two very distinct radulae (i.e., teeth structure in gastropods). However, up until this study, only eight specimens spanning a small fraction of the known geographic area of this group (Vanuatu) were available.

The objective of the study is to revise the species delimitation in the Xenuroturris / Iotyrris complex using an increased number of specimens from a large geographic range, combining (i) the barcode fragment of the COI gene analyzed using several species delimitation methods (ABGD, GMYC, mPTP) in order to propose Primary Species Hypotheses (PSH); (ii) a genome wide RAD sequencing approach, a method adapted to non-model organisms (Kess, Gross, Harper, \& Boulding, 2015), analyzed through tree reconstruction (using IQ-tree) and using the BFD species delimitation methods to test the alternative partitions of PSH proposed with the COI gene; and (iii) morphological, anatomical and geographic data to propose Secondary Species Hypotheses (SSH) in an integrative taxonomy context, where species, 
defined as definitely diverging lineages, are considered as hypotheses engaged in a process of validation or modification (Barberousse \& Samadi, 2010; De Queiroz, 2007).

\section{MATERIAL AND METHODS}

\section{Material}

Specimens belonging to the Xenuroturris / Iotyrris species complex were collected during several field expeditions organized by the MNHN (Muséum National d'Histoire Naturelle): "Santo 2006" in Vanuatu, "Terrasses" in New Caledonia, "Inhaca 2011" and "Mainbaza” in Mozambique, “Atimo Vatae” in Madagascar, "Papua-Niugini” in Papua-New-Guinea and "Pakaihi I Te Moana” in the Marquesas Islands); by joined Russian-Vietnamese tropical center (Vietnam); by the University of Utah in collaboration with the University of the Philippines (Philippines) and by P. Stahlschmidt in Egypt (Fig. 1). Specimens were routinely collected with use of SCUBA equipment, almost exclusively during night dives. Specimens were removed from the shell by using an isotonic solution of the magnesium chloride until relaxed (before 2012) or processed with the use of microwave (Galindo, Puillandre, Strong, \& Bouchet, 2014). As part of another project, some shells were broken to access the venom glands; in these cases, the shells were photographed first. In all cases, a tissue-clip was preserved in ethanol. Voucher shells and the body of the molluscs were kept for future morphological studies; all vouchers were deposited in the MNHN collections and specimen data and COI sequences were submitted to BOLD and GenBank (Table 1). Because the monophyly of the species complex was demonstrated previously (see e.g. Puillandre et al., 2012), only one closely related outgroup was included (Lophiotoma jickelli, Turridae). 
141 A total of 95 samples were analyzed; up to 12 samples were collected per locality and per morphospecies. However, most species in this complex are quite rare, and for some morphospecies and/or locality, only one sample was available. Furthermore, the RADsequencing was not successful for several samples (see below), thus reducing the number of samples per morphospecies and locality, but still retaining at least one sample per locality and per morphospecies (Table 1).

\section{Sanger sequencing and primary species hypotheses}

DNA was extracted using the Epmotion 5075 robot (Eppendorf), following the manufacturers' recommendations. A fragment of the COI gene was amplified using universal primers LCO1490/HCO2198 (Folmer, Black, Hoeh, Lutz, \& Vrijenhoek, 1994). PCR reactions were performed in $25 \mu$, containing $3 \mathrm{ng}$ of DNA, $1 \mathrm{X}$ reaction buffer, $2.5 \mathrm{mM}$ MgCl2, $0.26 \mathrm{mM}$ dNTP, $0.3 \mathrm{mM}$ of each primer, 5\% DMSO, and 1.5 units of Qbiogene QBio Taq. Amplification consisted of an initial denaturation step at $94^{\circ} \mathrm{C}$ for $4 \mathrm{~min}$, followed by 35 cycles of denaturation at $94^{\circ} \mathrm{C}$ for $30 \mathrm{~s}$, annealing at $50^{\circ} \mathrm{C}$ for COI, followed by extension at $72^{\circ} \mathrm{C}$ for $1 \mathrm{~min}$. The final extension was at $72^{\circ} \mathrm{C}$ for 5 min. PCR products were purified and sequenced by the Eurofins sequencing facility (France).

Chromatograms were edited using CodonCode Aligner v. 3.7.1.1 (CodonCode Corporation, Dedham, MA; www.codoncode.com). Sequences were aligned using MUSCLE (Edgar, 2004), and the accuracy of the alignment was checked by eye. Maximum Likelihood analyses (ML) were performed using RAxML 7.0.4 (Stamatakis, 2006), with a GAMMA model applied independently to each codon position. Accuracy of the results was assessed by bootstrapping (1000 replicates). Bayesian Analyses (BA) were performed running two parallel analyses in MrBayes (Huelsenbeck, Ronquist, \& Hall, 2001), consisting each of eight 
Markov chains of 200,000,000 generations each with a sampling frequency of one tree each 10,000 generations. The number of swaps was set to five, and the chain temperature at 0.02 . Similar to the ML approach, unlinked models (each with six substitution categories, a gamma-distributed rate variation across sites approximated in four discrete categories and a proportion of invariable sites) were applied for each partition. For both MrBayes and BEAST (see below) analyses, convergence was evaluated using Tracer 1.6 (Rambaut \& Drummond, 2014), to confirm that the ESS values were $>200$. A consensus tree was then calculated after omitting first 25\% trees as burn-in. RaxML, MrBayes and BEAST (see below) analyses were performed on the Cipres Science Gateway (http:// www.phylo.org/portal2/) using the RAxML-HPC2 on TG, MrBayes on XSEDE (3.2.6) and BEAST on XSEDE (1.8.2) tools, respectively.

Three methods of species delimitation were applied to propose PSH: (i) ABGD (Automatic Barcode Gap Discovery; Puillandre, Lambert, et al., 2012), which automatically detects a gap in the distribution of pairwise genetic distances, making the assumption that it corresponds to a threshold between intra and interspecific distances; GMYC (General Mixed Yule Coalescent model; (Fujisawa \& Barraclough, 2013; Monaghan et al., 2009; Pons et al., 2006), which tests whether branching rates along an ultrametric tree fits better with a speciation model or a coalescent model, using the transition point between speciation and coalescence to delimit species hypotheses; and (iii) PTP (bayesian Poisson Tree Processes; Zhang et al., 2013), which also compares speciation and coalescent models but relies on substitution rates calculated for each nodes instead of branching rates. The webserver available at http://wwwabi.snv.jussieu.fr/public/abgd/ (version of March 2017) was used for ABGD, with the default parameters. The distance matrix was computed by ABGD, using the Jukes-Cantor substitution model. BEAST 1.8.1 (Drummond \& Rambaut, 2007) was used to obtain a 
relative-rates ultrametric tree for the GMYC and PTP analyses, with a relaxed lognormal clock and a coalescent prior, determined as the best-fitting parameters to be used with the GMYC model (Monaghan et al., 2009). A GTR+I+G substitution model was applied, and the Metropolis coupled Markov chains (MCMC) were run for 100,000,000 generations. GMYC (both single and multiple versions), PTP and mPTP (Kapli et al., 2016; Monaghan et al., 2009; Pons et al., 2006; Zhang et al., 2013) were run using the webservers at species.h-its.org and mptp.h-its.org (versions of March 2017), respectively, using default parameters.

\section{$\underline{\text { RAD-sequencing }}$}

Single digest RAD sequencing (Baird et al., 2008) was conducted using the restriction enzyme SbfI on 95 samples. Barcoded Illumina library preparation and sequencing was subcontracted to Eurofins. Classical libraries were constructed and single-end sequenced on two lanes of Illumina HiSeq 2000. The sequencing resulted in a total of 293 million reads.

Reads were demultiplexed according to the 10 base long barcodes with the allowance of one mismatch using fastx barcode splitter from the FASTX-Toolkit suite (http://hannonlab.cshl.edu/fastx_toolkit/). Seven million reads remained unassigned. The number of reads per sample varied from 6700 to 23 million with a mean of 2.9 million. Reads quality was checked using FastQC (http://www.bioinformatics.babraham.ac.uk) for each sample individually. Since part of the samples indicated quality drops after 70-80 bases, the ends of reads were cleaned-up following a sliding window approach using Fastq quality trimmer also from the FASTX-Toolkit suite. Reads were cleaned from the 3' end using a window size of five, a step size of one and an average minimum score within the window of 20. Following clean-up, reads were checked again using FastQC to make sure quality profiles were satisfying. 
213 Usable loci were produced from raw reads using pyRAD 3.01 (Eaton, 2014). The choice of

214 this pipeline was made according to the fact that both 1) the presence of indels (which was

215 anticipated between more distant samples) and 2) the trimming of reads result in variable reads length which is not allowed in the more commonly used pipeline STACKS (Catchen, Hohenlohe, Bassham, Amores, \& Cresko, 2013). Several combinations of parameters were used and quickly revealed that samples with less than 1 million reads resulted in low numbers of usable loci leading to long branches artifacts. Such samples were discarded to obtain the final dataset with the 66 remaining samples, including one outgroup (Table 1). Once discarding these samples, the outputs of pyRAD were relatively stable. Among the 66 samples treated here, 46 were micro-waved to remove the mollusk from its shell. The average number of reads obtained per sample was slightly higher for the micro-waved samples $(3,971,187)$ than for the non micro-waved ones $(3,290,728)$, confirming than the micro-waves do not damage the DNA. The higher number of reads for the micro-waved samples could be explained by the fact that the micro-waved samples were also more recently collected. A minimum coverage (Mindepth) of five reads was used, as well as a clustering threshold (Wclust) of 0.89, and a minimum of two samples shared by any locus (MinCov). A maximum likelihood tree was produced using IQ-tree (Nguyen, Schmidt, von Haeseler, \& Minh, 2014). We estimated the best substitution model for each locus with ModelFinder (Kalyaanamoorthy, Minh, Wong, von Haeseler, \& Jermiin, 2017) following the BIC criterion. We then applied 1000 ultrafast bootstrap (UFBoot) (Hoang, Chernomor, von Haeseler, Minh, \& Le, 2017) on each dataset to obtain branch support. The same tree reconstruction was also conducted only keeping one SNP per locus and resulted in a similar topology. In order to test the effect of the parameter MinCov, which has a direct impact on the level of missing data in the final outputs, we also generated datasets corresponding to data missing for up to 30, 40, 
$50,60,70$ and $80 \%$ of the samples (i.e. the maximum percentage of samples not having information for a specific locus to be kept, corresponding to MinCov values of 46, 40, 33, 26, 20 and 13, respectively). For each dataset, the total number of loci, the total number of SNP as well as the percentage of nodes in the IQ-tree showing a bootstrap value above75 and 95 were calculated.

The RAD-seq dataset was also analyzed with BFD to test alternative partition of species (see below) proposed by ABGD, GMYC or PTP with the COI dataset. MLE (Marginal Likelihood Estimates) for each partition of species were obtained using the implementation of BFD* in the SNAPP (Bryant, Bouckaert, Felsenstein, Rosenberg, \& RoyChoudhury, 2012) plug-in for BEAST v2.5 (Bouckaert et al., 2014). Given the high number of loci and the high level of missing data, we kept only the $10 \%$ of loci with the lowest level of missing data (corresponding to 470 loci) and performed multiple runs with various number of steps $(20,50$, 100 and 200) and chain length (100,000 and 500,000) for the path-sampling, with a preburnin of 50,000. Bayes Factors (BF) were calculated from the MLE for each model pair. We followed Grummer, Bryson Jr, \& Reeder (2013) in recognizing a $2 \ln B f>10$ as “decisive” support in distinguishing between competing species delimitation hypotheses.

\section{$\underline{\text { Secondary species hypotheses }}$}

The PSH proposed with ABGD, GMYC and PTP were compared with the results obtained with the RAD-seq data. Because specimens from the same species are supposed to recombine on independent loci, contrary to specimens from different species, intraspecific relationships inferred from these two datasets are expected to be different; conversely, interspecific relationships are expected to be more congruent in both COI and RAD-seq trees (Pante, Puillandre, et al., 2015). Based on this property, we looked for PSH defined with the COI 
gene that corresponded to clades in the phylogenetic tree obtained with the RAD-seq data (i.e.

262

263 all the specimens of a COI PSH cluster together in a single clade in the RAD-seq tree), a pattern in support of the hypothesis that these PSH are actually different SSHs. We applied the integrative taxonomy flowchart described in (Puillandre, Modica, et al., 2012) to add arguments in favor of one or two SSHs, when two PSHs are compared. In particular, we analyzed species distribution patterns: an overlapping distribution between two sister-PSHs would support the hypothesis that they correspond to two different SSHs; an allopatric distribution is less informative, since although it demonstrates limited gene flow between populations, it does not allow judgments on whether the distant populations are two reproductively isolated species. All the analyzed specimens exhibit a multispiral protoconch, indicative of planktotrophic development (Jablonski \& Lutz, 1980) and suggestive of high dispersal capabilities.

A previous study (Kantor et al., 2008) demonstrated that in Xenuroturris/Iotyrris complex the shell shape cannot be considered as a reliable character for delimitation of the species, with intraspecific variation exceeding the interspecific one. On the contrary, the spiral sculpture as well as coloration of teleoconch appeared to be important diagnostic characters. Therefore we paid special attention to the sculpture of the subsutural zone (subsutural ramp) and the zone of anal sinus (sinus cords) as well as color pattern of studied species. The teleconch characters were compared to the type specimens of known species in the group to link the species hypotheses to available species names. Because the radula has been shown to be variable within this complex, several specimens per PSHs (when possible, selected from the sequenced material) were dissected to identify the radula type. Radulae were prepared by standard methods (Kantor \& Puillandre, 2012) and examined by scanning electron microscope TeScan 
TS5130MM in the Institute of Ecology and Evolution of Russian Academy of Sciences (IEE RAS). Terminology used for radula description follows Kantor (2006).

\section{RESULTS}

For clarity, the species names used from here onwards are attributed to either Xenuroturris or Iotyrris following the results of the phylogenetic analysis: X. legitima Iredale, 1929, I. cingulifera (Lamarck, 1822), I. notata (Sowerby, 1889), comb. nov., I. kingae (Powell, 1964), comb. nov. I. devoizei Kantor, Puillandre, Olivera \& Bouchet, 2008, I. olangoensis (Olivera, 2002), comb. nov., I. conotaxis n. sp., I. musivum Kantor, Puillandre, Olivera \& Bouchet, 2008.

\section{$\underline{\text { Results of the exploratory approach }}$}

When ABGD is used with default parameters, two groups corresponding to the main lineages (identified as two different genera in Kantor et al., 2008) were detected. Therefore, we analyzed each genus separately with ABGD. In the vicinity of the barcode gap (i.e. 2-6\%), ABGD consistently defines 2 PSH within the first lineage (Xenuroturris) and 11 PSHs in the second (Iotyrris), with both the initial and recursive approaches (Fig. 2). As shown on the figure 2, species names available in the literature were attributed to the PSH through the comparison of shell morphology to the known species, including the type specimens; one PSH, consistently defined by all the methods, could not be attributed to an available name and is thus described as a new species (I. conotaxis n. sp. - see below). Within X. legitima, I. cingulifera, I. devoizei and I. conotaxis n. sp., two allopatric lineages are recognized, one in the Indo-West Pacific Ocean (IWP - Vietnam, Philippines, Vanuatu, Chesterfield and Marquesas Islands), and the second in the West-Indian Ocean (WIO - Mozambique and 
Madagascar). Similar partitions are also found with the single version of GMYC, the PTP and the mPTP methods (the multiple version of GMYC returns an unrealistic number of PSHs 21, a result reported previously - e.g. (Fujisawa \& Barraclough, 2013; Kekkonen \& Hebert, 2014; Talavera, Dincă, \& Vila, 2013). The exceptions are the following: with mPTP, the two lineages of I. devoizei and I. kingae are grouped in a single PSH; within I. olangoensis, two specimens, the unique one from Vanuatu, and one of the Philippines specimens, are considered as one or two PSH, in addition to a PSH, consistently found by all the methods, grouping the other specimens of I. olangoensis from the Philippines. Finally, the mPTP method groups in a single PSH the two allopatric lineages within I. conotaxis n. sp. Remarkably, the two specimens from Egypt do not cluster in the same PSH: one clusters in the IWP PSH of I. cingulifera, the other in the WIO PSH of I. cingulifera with all methods.

$\underline{\text { RAD-seq and secondary species hypotheses }}$

Several sets of parameters were tested using the pipeline pyRAD for the generation of the alignment used for tree reconstructions. Unlike most other parameters tested, the parameter MinCov, corresponding to the minimum number of samples with information needed to keep a locus in the final dataset, had a strong effect on the number of loci and SNP recovered from our RAD-seq data. The number of loci recovered varied from 2 to 17,060 and the number of total SNP from 22 to more than 97,393 when MinCov was changed in order to maintain 30 to $80 \%$ of the samples having information as the cut-off to keep a locus (Table 2). Nevertheless, even though adding more loci directly increases the percentage of missing data in a dramatic way, the topologies obtained were congruent with each other, when the supported nodes (Bootstraps values above 95) were considered (Fig. 2, Supp. Mat. 1). Moreover, those obtained with more loci and thus more missing data were better resolved: nodes with 
bootstrap values more than 75 and 95 increase from 8 to $90 \%$ and from 3 to 65\%, when MinCov is reduced from 46 to 13, respectively. This increase in number of supported nodes followed a linear function, with a higher correlation $\left(\mathrm{R}^{2}=0.95\right)$ for nodes with bootstraps values above 95 than for nodes with bootstraps values above $75\left(\mathrm{R}^{2}=0.79\right)$. This likely occurred because the number of nodes with bootstraps values above 75 reached a maximum with the dataset containing $70 \%$ of missing data (92\%), then decreasing to $90 \%$ with the dataset containing $80 \%$ of missing data. With a MinCov value of 2 , the dataset included 103,060 loci after paralog removal.

The clades recovered with the RAD-seq data are congruent with the PSHs, or groups of PSHs, as defined with the COI (Fig. 2). The PSHs X. legitima, I. cingulifera, I. notata, I. kingae, I. devoizei and I. olangoensis are found as independent lineages in the RAD-seq tree. In the more supported IQ-trees (obtained with 50 to $80 \%$ of missing data), these PSH are always recovered with high support, but the relationships within each of these PSH change from one tree to another. One exception is the clade that unites I. musivum and I. conotaxis n. sp.: these two PSHs are not always recovered because the position of the unique sample from the WIO, IM-2009-6456, constant moves from one PSH to the other. This pattern is probably artefactual, since this sample is the one with the lowest number of reads and loci. When this sample is removed, the pattern for $I$. musivum and $I$. conotaxis n. sp. are similar to the other species, with both PSH being always recovered as a fully supported clades in the IQ-trees, but with internal relationships changing from one tree to another.

The allopatric lineages within X. legitima, I. cingulifera and I. devoizei are not monophyletic in the RAD-seq tree. Furthermore, the monophyly of the WIO clade of X. legitima was not supported with the the COI gene and the monophyly of the IWP clade of I. cingulifera was supported only in the Bayesian tree of the COI gene. The two specimens (MNHN-IM-2009- 
33561 and MNHN-IM-2009-24959) considered as separate PSH by some methods with the

357 COI gene within I. olangoensis are embedded within the other I. olangoensis PSH in the RAD-seq tree.

For the two PSH that include allopatric lineages and sufficient number of samples, $X$. legitima and I. cingulifera, the BFD method was used to test the two alternative scenarios: one species with an Indo-Pacific distribution, or two allopatric (WIO vs. PO) species each. To reduce computation time, each dataset was analyzed separately, together with one sample (IM-201340060, the most complete sample in terms of reads and loci recovered) used as an outgroup. Whatever the number of steps and the chain length used for the path sampling, the MLE values recovered for the partition with only one species is always lower than for the partition with two allopatric species, with 2lnBf values all greater than 100 (Table 3).

Given all these data, the PSHs were turned into 8 SSHs, represented as grey boxes in the Figure 2, as follows:

- the two allopatric lineages within $X$. legitima are not found in the RAD-seq dataset and not supported as the best model in the BFD analysis, they have the same radula type (see below) and similar shells: they are considered a single SSH, named $X$. legitima; - the two allopatric lineages within I. cingulifera are not found in the RAD-seq dataset and not supported as the best model in the BFD analysis, they have the same radula type and similar shells: they are considered a single SSH, named I. cingulifera;

- I. notata is consistently recognized as an independent group with all datasets and methods, and the radula type and the shells are similar among studied specimens; it is considered as a $\mathrm{SSH}$ 
- I. kingae, although grouped with I. devoizei with mPTP, is morphologically (both shell and radula) and genetically different from $I$. devoizei, therefore, it is considered as an independent $\mathrm{SSH}$

- the two allopatric lineages within I. devoizei are not found in the RAD-seq dataset, they have the same radula type and similar shells: they are considered a single SSH, named I. devoizei; - the two specimens (MNHN-IM-2009-33561 and MNHN-IM-2009-24959) that fall outside the main clade of I. olangoensis in the COI tree, are not isolated with the RAD-seq data. The shell and radula are consistent among all the I. olangoensis specimens, and it is thus considered a single SSH;

- I. conotaxis n.sp. is consistently found separate from the other lineages, with both COI and RAD-seq data. Although radula type in specimens from this lineage is the same as in $I$. musivum, both species are genetically and morphologically (see species description below) distinct, and I. conotaxis n. sp. is considered a single SSH. The placement of the single specimen from the WIO remains uncertain, either as sister to $I$. conotaxis n. sp. or to $I$. musivum. The shell morphology of this single specimen is not conclusive as it is a subadult from deeper waters (80-90m) compared to the IWP samples, and its morphology slightly differs from the adult shells of both I. conotaxis n. sp. and I. musivum. More specimens of this clade from the WIO are necessary to conclude.

- I. musivum is consistently found as a single PSH, and is considered a single SSH.

Shell and radular morphology is congruent with the eight defined SSH. The examination of numerous specimens allowed concluding that the most informative characters of the shell are the spiral sculpture and color pattern of the subsutural ramp and sinus cords. The subsutural ramp is the zone below the suture, which in Xenuroturris and Iotyrris is delimited by narrow but distinct abapical groove. It bears three to five cords, varying interspecifically in width and 
coloration: cords can have numerous dark speckles limited to cords or large subrectangular spots, that extend to the interspaces between cords (I. devoizei, I. kingae, I. olangoensis). Sinus cords are distinct elements of the spiral sculpture, originating at the posterior part of the anal sinus (Fig. 4B). Originally paired, they can be subdivided by narrow longitudinal grooves. The pattern of this subdivision as well as the coloration of the cords are also important diagnostic characters. Although there is no single character that allows recognition of all studied species, each defined SSH has its own combination of characters states. The summary of diagnostically important shell characters is provided in Table 4.

The radula in studied species of Xenuroturris / Iotyrris complex is rather variable; two major radular types can be recognized, differing in the morphology of the marginal teeth (Fig. 3). In the first type the marginal teeth have duplex shape, typical for Turridae and many other Conoidea. The anterior part of the tooth (closer to the tip), up to half of total tooth length, is solid, while the posterior part has two thickened edges, a thinner dorsal one (the accessory limb) and a thicker ventral one (the major limb) attached to the radular membrane (Fig. 3 AD). The second radular type is characterized by "semi-enrolled" marginal teeth. Both edges of the marginal teeth are elevated and equally developed along the entire tooth length, and they delimit an intervening trough. The anterior solid part of the tooth is absent (Fig. 3 E-F; 5). This second type is unique in the family Turridae and is confined only to the genus Iotyrris. Nevertheless, we found that the radular types were not correlated with the phylogenetic relationships: X. legitima, I. notata, I. kingae and I. olangoensis have the duplex marginal radular teeth, while I. cingulifera, I. devoizei, I. conotaxis n. sp. and I. musivum have the semi-enrolled marginal teeth.

\section{Species description:}


Superfamily CONOIDEA Fleming, 1822

Family TURRIDAE H. \& A. Adams, 1853 (1838)

Genus Iotyrris Medinskaya \& Sysoev, 2001

Iotyrris conotaxis n. sp. (Figs 4, 5)

ZooBank registration: urn:lsid:zoobank.org:act:4FB76AA0-1519-4361-A3D94E47F002ABAA

Holotype: MNHN-IM-2009-33570. Paratypes, MNHN-IM-2009-33539, MNHN-IM-200933564, both from type locality.

Type locality: Philippines, Olango Island, off Cow-Oy, 15-20 m, collected during night dive.

DESCRIPTION (HOLOTYPE). Shell conical, consisting of 9.75 evenly convex teleoconch whorls, with high spire; shell diameter to shell height 0.34 , aperture height (without canal) to shell height 0.28 , spire height to shell height 0.49 . Protoconch brown, partially eroded, remaining part of 4.25 convex whorls, sculptured with closely spaced axial arcuate threads, slightly prosocline, nearly orthocline on most whorls, but turning to strongly opisthocline on posteriormost part of last protoconch whorl. 26 threads on last protoconch whorl. 4-5 early teleoconch whorls nearly flat, slightly angulated at shoulder. Late teleoconch whorls convex in outline, particularly the last whorl. Last whorl sharply narrowing towards attenuated but short nearly straight siphonal canal. Suture deeply impressed, slightly wavy, nearly canaliculate due to raised subsutural cord. Subsutural ramp narrow, on last whorl with three distinct broadly spaced thin nodulose cords, with interspaces twice broader than cords. Abapical edge of subsutural ramp with very narrow but deep groove, sometimes obscured by 
nodulose edges of minor cords. This groove clearly seen on apertural lip, bordered by narrow cord. Two strongly raised subequal in width sinus cords, triangular in section abut subsutural ramp. Whorls portion below sinus cords sculptured with subequal narrow cords, from one on uppermost teleoconch whorls to four on penultimate whorl. On last whorl, seven subequal spiral cords below sinus before transition to canal, and 15 weaker cords on shell base and canal with narrow thread between some of them. Axial sculpture absent, except for inconspicuous growth lines. Aperture narrowly oval. Outer lip thin, evenly rounded. Anal sinus deep, U-shaped, situated on the shoulder. Inner lip slightly convex, columellar part straight, callus very narrow, not extending onto the parietal wall. Canal delimited from aperture by inconspicuous fold. Colour creamy white, with regularly spaced, light-brown spots covering cords of the entire shell surface and much more pronounced, strong, darker subrectangular spots on sinus cords. Subsutural ramp with light-brown irregularly shaped blurring spots, in some parts of shells merged, producing uniform brown subsutural ramp. Shell height $32.8 \mathrm{~mm}$, shell diameter $11.1 \mathrm{~mm}$, last whorl height $16.8 \mathrm{~mm}$, aperture height (without canal) $9.2 \mathrm{~mm}$.

Radula was examined in three specimens: MNHN-IM-2009-29714 (Vietnam), MNHN-IM2009-33539 and MNHN-IM-2009-33548 (Philippines) (Fig. 5). It is very similar in all specimens, formed by semi-enrolled unbarbed marginal teeth, edges of the marginal teeth are elevated and equally developed along entire tooth length, and delimit a trough. The anterior solid part of the tooth is absent. The marginal teeth on both sides of the radular membrane are interlocked, so that tooth of one row is lying within the trough of a tooth of the subsequent row. Central formation is formed by a small and short central cusp and more or less developed lateral flaps. 
476 Remarks. The species is represented in our material by six specimens, five from Olango

477 Island, in the Philippines and one from Vietnam. Although most specimens were collected by

478 hookah divers in the Philippines and the exact depth is not known, the usual operation depths

479 during collecting in Olango Island is $15-20 \mathrm{~m}$, while the specimen from Vietnam was

480 collected by SCUBA at similar depths (15-22 m). The largest specimen reaches $36.7 \mathrm{~mm}$ in

481 length.

482

All available specimens are rather similar in shell shape and colouration, most variable

483 is the degree of development of light brown spots on subsutural ramp, sometimes absent on

484 most of whorl, but always present at least on some parts.

485 There is not a single pure diagnostic character for I. conotaxis n. sp. in the COI

486 alignment.

The species is most similar to the closely related Iotyrris musivum; the two species sympatric and probably syntopic in Olango Island and also occur syntopically in Nha-Trang

Bay in Vietnam (Figs 6, 7). Despite the strong similarity, the new species can be reliably

distinguished from I. musivum by the presence of brown spots on, or sometimes nearly

completely brown subsutural ramp, which is creamy in I. musivum. Both species have similar

492

493 radulae with semi-enrolled marginal teeth. There is some similarity between the new species and I. olangoensis, also sympatric and syntopic in Philippines and Vietnam, but I. conotaxis n. sp. can be readily distinguished by the presence of distinct brown spots on the sinus cords, which are only speckled in I. olangoensis. Besides the two species differ in the radular morphology as I. olangoensis has duplex-type marginal teeth. 


\section{DISCUSSION}

500

501

502

503

504

505

506

507

508

509

510

511

512

513

514

515

516

517

518

519

520

521

522

\section{Diversity in the Xenuroturris / Iotyrris complex}

The combination of both exploratory (ABGD, GMYC and PTP) and hypothesis-testing (BFD) methods allowed us to delimit eight SSH in the Xenuroturris / Iotyrris complex, one of which being described as a new species. All these SSH are supported by both the mitochondrial and nuclear datasets, but also by diagnostic features of the shells and the radula. Although only two main types of radula morphology are recognized in the species complex, closely related species can possess different radula types (e.g. I. olangoensis vs I. conotaxis and I. musivum). Indeed, the distribution of the two radula types in the phylogenetic tree, with species exhibiting the same radula type not clustering together, raises taxonomic and evolutionary questions. Previously the radular type (semi-enrolled versus duplex marginal teeth) was considered as a reliable character to differentiate the genera Iotyrris Medinskaya \& Sysoev, 2001 (type species I. marquesensis Sysoev, 2002) with semi-enrolled teeth and Xenuroturris Iredale, 1929 with the duplex ones (Kantor et al., 2008). The originally monotypical Iotyrris Medinskaya \& Sysoev, 2001 was described on the presence of a semi-enrolled marginal radular teeth, unique - at that time - for the Turridae. The type species, I. marquesensis, was not and is still not sequenced. With the enlarged dataset the situation became more complex: three species with duplex marginal radular teeth were confidently placed into Iotyrris clade, namely Iotyrris olangoensis, I. notata and I. kingae, and the supposed congruence between the phylogeny and the radula type is thus no longer true. It may also appear that $I$. marquesensis may not belong to this clade and therefore the use of the name Iotyrris may not be appropriate, or the name itself may appear to be a synonym. Furthermore, within the same type (semi-enrolled or duplex teeth), the radular morphology can be quite different. Thus in $I$. marquesensis the semi-enrolled marginal teeth have distinct barb on the dorsal limb (Sysoev, 
2002): Fig. 2 C-D), which is not pronounced in any species here assigned to Iotyrris. The central formation is absent in I. marquesensis and I. cingulifera, while being rather distinct in I. devoizei and I. conotaxis n. sp. Similarly the shape of duplex radular teeth in the first radular type is quite variable, as well as the degree of development of the central formation (Fig. 3 A-D).

Contrary to what Kantor et al. (2008) have concluded ("radular type is indeed reliable for revealing relationships"), the evolution of the radulae types does not follow the phylogeny, and multiple convergence and/or reversion would be needed to explain the observed pattern. Remarkable is the difference in the radula between sister species (nearly identical in shell morphology and coloration) I. kingae and I. devoizei (Fig. $3 \mathrm{D}$ and F, correspondingly for radula and Fig. 7 for shells). One hypothesis is that the radula is more labile than is commonly assumed and its morphology in Turridae may be related to diet, as it has been shown in the related family Conidae (Kohn, Nishi, \& Pernet, 1999; Tucker \& Tenorio, 2009, p. 200). This hypothesis would also suggest that diet itself is labile, with closely related species being characterized by different diets, a hypothesis already proposed for cone snails (Kohn \& Orians, 1962). Identifying the preys would therefore be necessary to test a potential correlation between the radula type and the food habit, thus explaining the high lability of this anatomical structure.

There remains several non-sequenced species probably belonging to Xenuroturris / Iotyrris complex, some with known radular type (based on published and our unpublished data) -- $I$. marquesensis (semi-enrolled) (Fig. 7I), X. millepunctata (Sowerby, 1909) (duplex) (Fig. 7J), X. gemmnuloides Powell, 1964 (duplex), X. cerithiformis Powell, 1964 (duplex) (Fig. 7H), as well as the more enigmatic X.? castanella Powell, 1964 and X.? emmae Bozetti, 1993. Their generic position can be clarified only based on molecular studies. 
As emphasized in the introduction, DNA-based species delimitation methods are generally

designed either for less-known taxa, using monolocus data, to propose de novo species hypotheses, or for more difficult to tackle, species complexes, using multilocus data, to test pre-defined competing partitions of species. The two strategies, that we can term as “exploratory” and “hypothesis-testing”, respectively, are rarely combined. When predefined partitions of species are already available, and disagreements among taxonomists on species boundaries exist, exploratory methods will be mostly useless, and hypothesis-testing methods will be favored to identify the most likely species partition. On the contrary, when dealing with a largely unknown group, exploratory methods will be favored to propose PSH. Here we combined both strategies, applying a monolocus, COI barcode, dataset, and a multilocus, RAD-seq, dataset, being used to test alternative partitions proposed by the former. The methods applied to the COI dataset, now widely accepted as robust and congruent (see e.g. Kekkonen, Mutanen, Kaila, Nieminen, \& Hebert, 2015; Schwarzfeld \& Sperling, 2015), all proposed similar partitions in the case of the Xenuroturris / Iotyrris complex. However, each method has their own limitations (Carstens et al., 2013; Miralles \& Vences, 2013; Reid or to the quality of the input phylogenetic tree, sensitivities to the quality of the sampling (Ahrens et al., 2016; Hamilton, Hendrixson, Brewer, \& Bond, 2014)), justifying the use of several methods.

More importantly, most of the PSH proposed with the COI gene were confirmed by the analysis of the RAD-seq dataset. Interestingly, the phylogenetic reconstructions based on RAD-seq datasets exhibiting varying levels of missing data were quite congruent. Trees based 
on more loci, but consequently on higher levels of missing data, were better resolved, even for deeper relationships. This counter-intuitive result has been observed and discussed recently by several studies (see Eaton, Spriggs, Park, \& Donoghue, 2017; Tripp, Tsai, Zhuang, \& Dexter, 2017 for recent reviews). Consensus on the position to deal with missing data in RAD-seq analysis has not been reached and several studies strongly advocate for a case to case approach since in some situations, as selecting loci to decrease the proportion of missing data can possibly generate a strong bias (see for example Huang \& Knowles, 2014).

In addition to the phylogenetic approach applied to the RAD-seq dataset, the BFD method clearly identified, for both $X$. legitima and $I$. cingulifera, the hypothesis considering all IndoPacific samples as only one species as the more likely. This was in comparison with a partition in two species each, one in the WIO and the other in the PO. Here again, the level of missing data probably led to unstable MLE when various number of steps and chain length for the path-sampling are used, but the important difference between the MLE of the two competing partitions convinced us that the BF was decisive.

Thus, the successive use of exploratory and hypothesis-testing methods was necessary to reject the hypothesis that allopatric populations with $X$. legitima and $I$. cingulifera constitute different species. Indeed, analyzing the COI dataset only would have led to recognize these allopatric populations as species, as supported by all the exploratory methods (Fig. 2). As exemplified here, the tree topology obtained with two distant populations within species can easily mimic the topology obtained with two sister species, even when considering the genetic distances: the genetic distances between the two allopatric pairs within $X$. legitima and $I$. cingulifera $(\mathrm{K} 2 \mathrm{P}$ distances $=1.7-3.6 \%)$ are actually similar to the genetic distances between I. devoizei and I kingae (1.5 - 2.6\%) and I. conotaxis, I. musivum and I. olangoensis (1.93\%). Applying various methods of species delimitation remains the best strategy to counter- 
balance the limitations of each, as discussed before, but more important is the joint analysis of independent genetic markers, since gene trees, taken independently, are not necessarily congruent with the species tree (Degnan \& Rosenberg, 2009).

Consequently, and except the case of I. devoizei and I. notata, all the species are present in sympatry (in the Philippines). However, a scenario in which allopatric speciation with subsequent changes in the distribution areas cannot be ruled out (Berlocher, 1998; Chesser \& Zink, 1994). Following the criteria of Coyne \& Orr (2004), determining the age of the speciation events could help to test these two scenarios, but in the absence of calibration points (either biogeographic events or fossils), we were not able to reconstructed a dated tree. Similarly, exploring whether, if Xenuroturris species may have diverged in sympatry (e.g. by niche partitioning linked to the apparition of new toxins and prey shifts (Duda \& Lee, 2009; Fedosov, Tiunov, Kiyashko, \& Kantor, 2014; Nicolas Puillandre et al., 2014)) or not would require sequencing the transcriptomes of the venom glands and identifying the preys of different species, and in particular, in the only pair of sympatric sister species, I. musivum and

\section{I. conotaxis sp. $\mathrm{n}$.}

\section{$\underline{\text { Conclusion }}$}

The combined use of classical barcoding, next generation sequencing and morphological observations enabled us to give new insight into the evolution of this species complex. Most defined SSH were linked to already described species and one new species is described. This study demonstrates the utility of combining both exploratory and hypothesis-testing methods. In the absence of primary species hypotheses, or, as it is the case here, when morphologybased species hypotheses are doubtful, analyzing monolocus data with exploratory methods such as ABGD, GMYC and PTP rapidly produces PSH. However, such PSH had to be taken 
cautiously, since high levels of divergence can also be observed between populations within species (and conversely, low genetic distances can results from a lack of variability between species for a given marker). Evaluating these PSHs with independent markers using a hypothesis-testing method constitutes a desirable strategy to tell apart SSH from e.g. populations within species.

\section{ACKNOWLEDGMENTS}

A large part of the molecular material in this paper originates from various shore-based expeditions and deep sea cruises, conducted respectively by MNHN (Inhaca 2011); by MNHN, Pro-Natura International (PNI) and Institut de Recherche pour le Développement (IRD) as part of the Our Planet Reviewed programme (Santo 2006, Atimo Vatae, Papua Niugini); and by MNHN and Institut de Recherche pour le Développement (IRD) as part of the Tropical Deep-Sea Benthos programme (Mainbaza, Terrasses, Pakaihi I Te Moana). Incountry partners include the Maritime College, Luganville; Universidade Eduardo Mondlane, Maputo and University of Papua New Guinea, Port Moresby. Funders and sponsors include the Total Foundation, Prince Albert II of Monaco Foundation, Stavros Niarchos Foundation, Richard Lounsbery Foundation, Vinci Entrepose Contracting, Fondation EDF, the French Ministry of Foreign Affairs, the French Fonds Pacifique and the Government of New Caledonia. The specimens from the Philippines used in this study were obtained by AF in conjunction with a collection trip supported in part by the 'Conus-Turrid’ project (principal investigator B. M. Olivera, University of Utah, USA). Collection of material in Vietnam was supported by the Russian-Vietnamese Tropical Center. We are thankful to the staff of the Tropical Center for assistance in organization of the field sampling and loan of some laboratory equipment. Peter Stahlschmidt collected the specimens from Egypt, with a permit 
643 from the Hurghada Environmental Protection and Conservation Association (Hurghada,

644 Egypt). All expeditions operated under the regulations then in force in the countries in 645 question and satisfy the conditions set by the Nagoya Protocol for access to genetic resources.

646 The authors also thank Virginie Héros, Julien Brisset, Philippe Maestrati and Manuel Caballer

647 Gutierrez for their help in curating specimens, and Mark Phuong, Sarah Samadi and

648 Guillaume Achaz for constructive comments on the manuscript. We are grateful to Dr. Norine

649 Yeung from Bishop Museum, Honolulu Hawaii for providing the photos of the types

650 of Xenuroturris kingae. This project was partly supported by the Service de Systématique

651 Moléculaire (UMS 2700 CNRS-MNHN) and by the project CONOTAX, funded by the

652 French ANR (grant number ANR-13-JSV7-0013-01). The contribution of Yu.I. Kantor and

653 A.E. Fedosov was supported by the grant No. 16-14-10118 from the Russian Science

654 Foundation (principal investigator Yu.I.Kantor). The scanning electron microscopy was

655 conducted using Joint Usage Center «Instrumental methods in ecology» at the IEE RAS.

656 


\section{REFERENCES}

Ahrens, D., Fujisawa, T., Krammer, H.-J., Eberle, J., Fabrizi, S., \& Vogler, A. P. (2016). Rarity and incomplete sampling in DNA-based species delimitation. Systematic Biology, 65(3), 478-494.

Baird, N. A., Etter, P. D., Atwood, T. S., Currey, M. C., Shiver, A. L., Lewis, Z. A., ... Johnson, E. A. (2008). Rapid SNP discovery and genetic mapping using sequenced RAD markers. PloS One, 3(10), e3376.

Barberousse, A., \& Samadi, S. (2010). Species from Darwin onward. Integrative Zoology, 5, 187-197.

Berlocher, S. H. (1998). Can sympatric speciation via host or habitat shift be proven from phylogenetic and biogeographic evidence. Endless Forms: Species and Speciation, 99-113.

Boucher, F. C., Casazza, G., Szövényi, P., \& Conti, E. (2016). Sequence capture using RAD probes clarifies phylogenetic relationships and species boundaries in Primula sect. Auricula. Molecular Phylogenetics and Evolution, 104, 60-72. doi:10.1016/j.ympev.2016.08.003

Bouckaert, R., Heled, J., Kühnert, D., Vaughan, T., Wu, C.-H., Xie, D., ... Drummond, A. J. (2014). BEAST 2: a software platform for Bayesian evolutionary analysis. PLoS Computational Biology, 10(4), e1003537.

Bryant, D., Bouckaert, R., Felsenstein, J., Rosenberg, N. A., \& RoyChoudhury, A. (2012). Inferring species trees directly from biallelic genetic markers: bypassing gene trees in a full coalescent analysis. Molecular Biology and Evolution, 29(8), 1917-1932.

Carstens, B. C., Pelletier, T. A., Reid, N. M., \& Satler, J. D. (2013). How to fail at species delimitation. Molecular Ecology, in press.

Catchen, J., Hohenlohe, P. A., Bassham, S., Amores, A., \& Cresko, W. A. (2013). Stacks: an analysis tool set for population genomics. Molecular Ecology, 22(11), 3124-3140.

Chesser, R. T., \& Zink, R. M. (1994). Modes of speciation in birds: a test of Lynch's method. Evolution, 48(2), 490-497.

Coissac, E., Hollingsworth, P. M., Lavergne, S., \& Taberlet, P. (2016). From barcodes to genomes: extending the concept of DNA barcoding. Molecular Ecology, 25(7), 14231428. doi:10.1111/mec.13549

Coyne, J. A., \& Orr, H. A. (2004). Speciation. Sunderland, Massachusetts.: Sinauer Associates.

De Queiroz, K. (2007). Species concepts and species delimitation. Systematic Biology, 56, 879-886.

Degnan, J. H., \& Rosenberg, N. A. (2009). Gene tree discordance, phylogenetic inference and the multispecies coalescent. Trends in Ecology and Evolution, 24(6), 332-340.

Drummond, A. J., \& Rambaut, A. (2007). BEAST: Bayesian evolutionary analysis by sampling trees. BMC Evolutionary Biology, 7, 214.

Duda, T. F., Jr., Bolin, M. B., Meyer, C., \& Kohn, A. J. (2008). Hidden diversity in a hyperdiverse gastropod genus: discovery of previously unidentified members of a Conus species complex. Molecular Phylogenetics and Evolution, 49, 867-876.

Duda, T. F., Jr., \& Lee, T. (2009). Ecological release and venom evolution of a predatory marine Snail at Easter Island. PLOS ONE, 4, e5558.

Eaton, D. A. (2014). PyRAD: assembly of de novo RADseq loci for phylogenetic analyses. Bioinformatics, 30(13), 1844-1849. 
Eaton, D. A., Spriggs, E. L., Park, B., \& Donoghue, M. J. (2017). Misconceptions on missing data in RAD-seq phylogenetics with a deep-scale example from flowering plants. Systematic Biology, 66(3), 399-412.

Ence, D. D., \& Carstens, B. C. (2011). SpedeSTEM: a rapid and accurate method for species delimitation. Molecular Ecology Resources, 11, 473-480.

Fedosov, A. E., Stahlschmidt, P., Puillandre, N., Aznar-Cormano, L., \& Bouchet, P. (2017). Not all spotted cats are leopards: evidence for a Hemilienardia ocellata species complex (Gastropoda: Conoidea: Raphitomidae). European Journal of Taxonomy, 268, 1-20. doi:10.5852/ejt.2017.268

Fedosov, A., Tiunov, A., Kiyashko, S., \& Kantor, Y. I. (2014). Trophic diversification in the evolution of predatory marine gastropods of the family Terebridae as inferred from stable isotope data. Mar. Ecol. Prog. Ser, 497, 143-56.

Folmer, O., Black, M., Hoeh, W., Lutz, R., \& Vrijenhoek, R. (1994). DNA primers for amplification of mitochondrial cytochrome c oxidase subunit I from diverse metazoan invertebrates. Molecular Marine Biology and Biotechnology, 3, 294-299.

Fujisawa, T., \& Barraclough, T. G. (2013). Delimiting Species Using Single-locus Data and the Generalized Mixed Yule Coalescent (GMYC) Approach: A Revised Method and Evaluation on Simulated Datasets. Systematic Biology. Retrieved from http://sysbio.oxfordjournals.org/content/early/2013/05/16/sysbio.syt033.abstract

Galindo, L. A., Puillandre, N., Strong, E. E., \& Bouchet, P. (2014). Using microwaves to prepare gastropods for DNA barcoding. Molecular Ecology Resources, 14(4), 700705. doi:10.1111/1755-0998.12231

Grummer, J. A., Bryson Jr, R. W., \& Reeder, T. W. (2013). Species delimitation using Bayes factors: simulations and application to the Sceloporus scalaris species group (Squamata: Phrynosomatidae). Systematic Biology, 63(2), 119-133.

Hamilton, C. A., Hendrixson, B. E., Brewer, M. S., \& Bond, J. E. (2014). An evaluation of sampling effects on multiple DNA barcoding methods leads to an integrative approach for delimiting species: a case study of the North American Tarantula genus Aphonopelma (Araneae, Mygalomorphae, Theraphosidae). Molecular Phylogenetics and Evolution, 71, 79-93.

Herrera, S., \& Shank, T. M. (2016). RAD sequencing enables unprecedented phylogenetic resolution and objective species delimitation in recalcitrant divergent taxa. Molecular Phylogenetics and Evolution, 100, 70-79. doi:10.1016/j.ympev.2016.03.010

Hoang, D. T., Chernomor, O., von Haeseler, A., Minh, B. Q., \& Le, S. V. (2017). UFBoot2: Improving the Ultrafast Bootstrap Approximation. Molecular Biology and Evolution, msx281.

Huang, H., \& Knowles, L. L. (2014). Unforeseen consequences of excluding missing data from next-generation sequences: simulation study of RAD sequences. Systematic Biology, syu046.

Huelsenbeck, J. P., Ronquist, F., \& Hall, B. (2001). MrBayes: Bayesian inference of phylogeny. Bioinformatics, 17, 754-755.

Jablonski, D., \& Lutz, R. A. (1980). Molluscan larval shell morphology - ecological and paleontological applications. In D. C. Rhoads \& R. A. Lutz (Eds.), Skeletal growth of aquatic organisms (pp. 323-377). New York: Plenum Press.

Kalyaanamoorthy, S., Minh, B. Q., Wong, T. K., von Haeseler, A., \& Jermiin, L. S. (2017). ModelFinder: fast model selection for accurate phylogenetic estimates. Nature Methods, 14(6), 587. 
Kantor, Y. I. (2006). On the morphology and homology of the "central tooth" in the radula of Turrinae (Conoidea: Turridae). Ruthenica, 16(1-2), 47-52.

Kantor, Y.I., Puillandre, N., Olivera, B. M., \& Bouchet, P. (2008). Morphological proxies for taxonomic decision in turrids (Mollusca, Neogastropoda): a test of the value of shell and radula characters using molecular data. Zoological Science, 25, 1156-1170.

Kantor, Yu. I., \& Puillandre, N. (2012). Evolution of the radular apparatus in Conoidea (Gastropoda: Neogastropoda) as inferred from a molecular phylogeny. Malacologia, 55, 55-90.

Kapli, P., Lutteropp, S., Zhang, J., Kobert, K., Pavlidis, P., Stamatakis, A., \& Flouri, T. (2016). Multi-rate Poisson Tree Processes for single-locus species delimitation under Maximum Likelihood and Markov Chain Monte Carlo. BioRxiv, 063875.

Kekkonen, M., \& Hebert, P. D. N. (2014). DNA barcode-based delineation of putative species: efficient start for taxonomic workflows. Molecular Ecology Resources, 14(4), 706-715. doi:10.1111/1755-0998.12233

Kekkonen, M., Mutanen, M., Kaila, L., Nieminen, M., \& Hebert, P. D. N. (2015). Delineating species with DNA barcodes: A case of taxon dependent method performance in moths. PLoS ONE, 10(4), e0122481. doi:10.1371/journal.pone.0122481

Kess, T., Gross, J., Harper, F., \& Boulding, E. G. (2015). Low-cost ddRAD method of SNP discovery and genotyping applied to the periwinkle Littorina saxatilis. Journal of Molluscan Studies, eyv042.

Kohn, A. J., Nishi, M., \& Pernet, B. (1999). Snail spears and scimitars: a character analysis of Conus radular teeth. Journal of Molluscan Studies, 65(4), 461-481.

Kohn, A. J., \& Orians, G. H. (1962). Ecological data in the classification of closely related species. Systematic Zoology, 119-127.

Leaché, A. D., Fujita, M. K., Minin, V. N., \& Bouckaert, R. R. (2014). Species delimitation using genome-wide SNP data. Systematic Biology, 63(4), 534-542.

Leavitt, S. D., Moreau, C. S., \& Lumbsch, H. T. (2015). The dynamic discipline of species delimitation: progress toward effectively recognizing species boundaries in natural populations. In Recent Advances in Lichenology (pp. 11-44). Springer.

Miller, M. R., Dunham, J. P., Amores, A., Cresko, W. A., \& Johnson, E. A. (2006). Rapid and cost-effective polymorphism identification and genotyping using restriction site associated DNA (RAD) markers. Genome Research, 17(2), 000-000.

Miralles, A., \& Vences, M. (2013). New metrics for comparison of taxonomies reveal striking discrepancies among species delimitation methods in Madascincus lizards. PLoS ONE, 8, e68242.

Monaghan, M. T., Wild, R., Elliot, ., Fujisawa, T., Balke, M., Inward, D. J. G., ... Vogler, A. P. (2009). Accelerated species inventory on Madagascar using coalescent-based models of species delineation. Systematic Biology, 58, 298-311.

Nguyen, L.-T., Schmidt, H. A., von Haeseler, A., \& Minh, B. Q. (2014). IQ-TREE: a fast and effective stochastic algorithm for estimating maximum-likelihood phylogenies. Molecular Biology and Evolution, 32(1), 268-274.

Pante, E., Abdelkrim, J., Viricel, A., Gey, D., France, S., Boisselier, M.-C., \& Samadi, S. (2015). Use of RAD sequencing for delimiting species. Heredity, 114(5), 450-459.

Pante, E., Puillandre, N., Viricel, A., Arnaud-Haond, S., Aurelle, D., Castelin, M., ... Samadi, S. (2015). Species are hypotheses: avoid connectivity assessments based on pillars of sand. Molecular Ecology, 24(3), 525-544. doi:10.1111/mec.13048 
Pons, J., Barraclough, T. G., Gomez-Zurita, J., Cardoso, A., Duran, D. P., Hazell, S., ... Vogler, A. P. (2006). Sequence-based species delimitation for the DNA taxonomy of undescribed insects. Systematic Biology, 55, 595-609.

Puillandre, N., Baylac, M., Boisselier, M. C., Cruaud, C., \& Samadi, S. (2009). An integrative approach of species delimitation in the genus Benthomangelia (Mollusca: Conoidea). Biological Journal of the Linnean Society, 96, 696-708.

Puillandre, N., Cruaud, C., \& Kantor, Y. I. (2010). Cryptic species in Gemmuloborsonia (Gastropoda: Conoidea). Journal of Molluscan Studies, 73, 11-23.

Puillandre, N., Kantor, Y., Sysoev, A., Couloux, A., Meyer, C., Rawlings, T., ... Bouchet, P. (2011). The dragon tamed? A molecular phylogeny of the Conoidea (Mollusca, Gastropoda). Journal of Molluscan Studies, 77, 259-272.

Puillandre, N., Lambert, A., Brouillet, S., \& Achaz, G. (2012). ABGD, Automatic Barcode Gap Discovery for primary species delimitation. Molecular Ecology, 21, 1864-1877.

Puillandre, N., Modica, M. V., Zhang, Y., Sirovitch, L., Boisselier, M.-C., Cruaud, C., ... Samadi, S. (2012). Large scale species delimitation method for hyperdiverse groups. Molecular Ecology, 21, 2671-2691.

Puillandre, N., Sysoev, A., Olivera, B. M., Couloux, A., \& Bouchet, P. (2010). Loss of planktotrophy and speciation: geographical fragmentation in the deep-water gastropod genus Bathytoma (Gastropoda, Conoidea) in the western Pacific. Systematics and Biodiversity, 8, 371-394.

Puillandre, Nicolas, Fedosov, A. E., Zaharias, P., Aznar-Cormano, L., \& Kantor, Y. I. (2017). A quest for the lost types of Lophiotoma (Gastropoda: Conoidea: Turridae): integrative taxonomy in a nomenclatural mess. Zoological Journal of the Linnean Society, 181(2), 243-271. doi:10.1093/zoolinnean/zlx012

Puillandre, Nicolas, Stöcklin, R., Favreau, P., Bianchi, E., Perret, F., Rivasseau, A., ... Bouchet, P. (2014). When everything converges: Integrative taxonomy with shell, DNA and venomic data reveals Conus conco, a new species of cone snails (Gastropoda: Conoidea). Molecular Phylogenetics and Evolution, 80(0), 186-192. doi:10.1016/j.ympev.2014.06.024

Raj, A., Stephens, M., \& Pritchard, J. K. (2014). fastSTRUCTURE: Variational Inference of Population Structure in Large SNP Data Sets. Genetics, 197(2), 573. doi:10.1534/genetics.114.164350

Rambaut, A., \& Drummond, A. J. (2014). Tracer v1.6. Available from http://beast.bio.ed.ac.uk/Tracer.

Reid, N. M., \& Carstens, B. C. (2012). Phylogenetic estimation error can decrease the accuracy of species delimitation: a Bayesian implementation of the general mixed Yule-coalescent model. BMC Evolutionary Biology, 12(1), 196.

Rutschmann, S., Detering, H., Simon, S., Fredslund, J., \& Monaghan, M. T. (2017). DISCOMARK: nuclear marker discovery from orthologous sequences using draft genome data. Molecular Ecology Resources, 17(2), 257-266.

Schwarzfeld, M. D., \& Sperling, F. A. (2015). Comparison of five methods for delimitating species in Ophion Fabricius, a diverse genus of parasitoid wasps (Hymenoptera, Ichneumonidae). Molecular Phylogenetics and Evolution, 93, 234-248.

Stamatakis, A. (2006). RAxML-VI-HPC: maximum likelihood-based phylogenetic analyses with thousands of taxa and mixed models. Bioinformatics, 22, 2688-2690.

Stamatakis, Alexandros. (2014). RAxML version 8: a tool for phylogenetic analysis and postanalysis of large phylogenies. Bioinformatics, 30(9), 1312-1313. 
Sysoev, A. (2002). On the type species of Iotyrris Mediskinya et Sysoev, 2001 (Gastropoda, Turridae). Ruthenica, 12, 169-171.

Talavera, G., Dincă, V., \& Vila, R. (2013). Factors affecting species delimitations with the GMYC model: insights from a butterfly survey. Methods in Ecology and Evolution, 4(12), 1101-1110.

Tripp, E. A., Tsai, Y. E., Zhuang, Y., \& Dexter, K. G. (2017). RADseq dataset with 90\% missing data fully resolves recent radiation of Petalidium (Acanthaceae) in the ultraarid deserts of Namibia. Ecology and Evolution, 7(19), 7920-7936.

Tucker, J. K., \& Tenorio, M. J. (2009). Systematic classification of Recent and fossil conoidean gastropods. Hackenheim, Germany: Conchbooks.

Yang, Z., \& Rannala, B. (2014). Unguided species delimitation using DNA sequence data from multiple loci. Molecular Biology and Evolution, msu279.

Zhang, J., Kapli, R., Pavlidis, P., \& Stamatakis, A. (2013). A general species delimitation method with applications to phylogenetic placments. Bioinformatics, Advance Access. 
859 - All samples are vouchered in the MNHN collection.

860 - Sample data and COI sequences will be uploaded in BOLD

861 - COI sequences will be uploaded in GenBank

862 - RAD-seq data and COI and RAD-seq trees have been uploaded in Dryad:

863 doi:10.5061/dryad.k2q42

\section{Author contributions}

866 JA and LAC performed the molecular experiments; BB vouchered and registered the samples; JA, PZ, and NP analyzed the data; AF and YK performed the morphological analyses and described the new species; NP, BB, AF and YK participated in the field sampling; all authors participated in the research design and wrote the manuscript. 
Table 1: Specimen list, with locality data, species names, BOLD and GenBank accession number (for the COI gene) and total number of reads, number of reads passing quality checks, total number of loci identified and number of loci present in the final dataset, shared with at least one other sample (for the RAD-seq dataset).

Table 2: Variation of the level of missing data (expressed as the maximum percentage of samples not having information for a specific locus to be kept) and its effect on the number of loci and SNP and percentage of nodes with bootstrap values $>50$.

Table 3: Results of the BFD analyses. For each species, two scenarios (one single species Vs two species in allopatry) were tested, for various numbers of steps and chain lengths. MLE values are reported for each analysis.

Table 4: Diagnostic character states for each studied species of the Xenuroturris / Iotyrris complex. 
Figure 1: Map of the collecting sites.

Figure 2: Bayesian tree (Mr Bayes) obtained with the COI dataset (left) and ML tree obtained with the RAD-seq dataset with $80 \%$ of missing data (right). Posterior Probabilities and bootstrap values are shown for each node in the COI tree for supported nodes only (Posterior Probabilities $>0.95$ and/or bootstrap values $>80$ ); bootstrap values (above 95) are shown for each node in the RAD-seq tree. For clarity, we removed the prefix of each sample number (IM-20XX); full samples numbers are provided in the Table 1. Species hypotheses proposed by ABGD, GMYC, PTP and mPTP are shown as vertical bars, as well as the locality for each specimen $(\mathrm{MO}=$ Mozambique, $\mathrm{MD}=$ Madagascar, $\mathrm{EG}=$ Egypt, $\mathrm{VI}=$ Vietnam, $\mathrm{PH}=$ Philippines, $\mathrm{PA}=$ Papua-New-Guinea, VA = Vanuatu and New Caledonia, $\mathrm{MR}=$ Marquesas). Grey boxes represent the final species hypotheses, with the species name, followed by the radula type (type 1 or type 2, shown on Fig. 3) and one illustrated shell. ${ }^{1}$ : specimens for which the radula has been observed.

Figure 3: Radula type 1 (A-D): duplex marginal teeth. A. Xenuroturris legitima Iredale, 1929, MNHN-IM-2009-24931, Mozambique. B. Iotyrris notata (Sowertby, 1889), MNHNIM-2009-29726, Vietnam. C. Iotyrris_olangoensis (Olivera, 2002), MNHN-IM-2009-33561, Philippines. D. Iotyrris kingae (Powell, 1964), MNHN-IM-2009-33554, Philippines. Radula type 2 (E-F): semi-enrolled marginal teeth.E. Iotyrris cingulifera (Lamarck, 1822), MNHNIM-2007-17686, Santo. F. Iotyrris devoizei Kantor, Puillandre, Olivera \& Bouchet, 2008, MNHN-IM-2009-24939, Mozambique. Scale bars - $50 \mu \mathrm{m}$.

Figure 4: Shells of Iotyrris conotaxis n. sp. A-C. Holotype, MNHN-IM-2009-33570, SL 33.2 mm. D. MNHN-IM-2009-29714, SL 27.9 mm, Vietnam, Nha-Trang Bay. E. Paratype, MNHN-IM-2009-33539, SL 32.1 mm. F-G. MNHN-IM-2009-33548, SL 30.7 mm. H. Paratype, MNHN-IM-2009-33564, SL 30.2 mm. I. MNHN-IM-2009-24996, SL 36.7 mm. All specimens except D from the type locality. All shells at the same scale.

Figure 5: Radulae of Iotyrris conotaxis n. sp. (A-D) and I. musivum (E-F). Iotyrris conotaxis n. sp.: A-B. MNHN-IM-2009-29714, SL 27.9 mm, Vietnam, Nha-Trang Bay (shell on Fig. 4 D). C. MNHN-IM-2009-33548, SL 30.7 mm, Philippines (shell on Fig. 4 F-G). D. MNHNIM-2009-33539, SL 32.1 mm, paratype, Philippines (shell on Fig. 4E). Iotyrris musivum: E. holotype, MNHN-IM-2009-26290, Vanuatu. F. Loyalty Islands, Atelier LIFOU 2000, st. 1421. Scale bars $-50 \mu \mathrm{m}$.

Figure 6: Shells of Xenuroturris / Iotyrris complex. A-D. Xenuroturris legitima. A. MNHNIM-2009-24936, Mozambique, SL 35.5 mm. B-B'. MNHN-IM-2009-17246, Madagascar, SL 12.3mm. C. MNHN-IM-2009-29710, Vietnam, SL 46.7 mm. D. MNHN-IM-2009-33532, Philippines, SL 47.3 mm. E-G. Iotyrris cingulifera. E. MNHN-IM-2009-24942, Mozambique, SL 37.9 mm. F. MNHN-IM-2009-29709, Vietnam, SL 53.9 mm. G. MNHNIM-2009-33545, Philippines, SL 39.9 mm. H-K. Iotyrris musivum. H. MNHN-IM-200929715, Vietnam, SL 33.9 mm. I. MNHN-IM-2009-24995, Philippines, SL 34.3 mm. J. MNHN-IM-2009-33557, Philippines, SL 30.1 mm. K. MNHN-IM-2009-24997, Philippines, SL 31.2 mm. L-M. Iotyrris olangoensis. L. MNHN-IM-2009-33561, Philippines, SL 31.4 mm. M. MNHN-IM-2009-24959, New Caledonia, SL 31.7 mm. N-O. Iotyrris notata. N. MNHN-IM-2009-29726, Vietnam, SL 40.2 mm. O. MNHN-IM-2009-29720, Vietnam, SL $28.9 \mathrm{~mm}$. All specimens sequenced. Shells at the same scale. The shells of the same species 
are arranged geographically in general direction from west to east. The colour background of the letters corresponds to the colours, used in the map on Fig. 1.

Figure 7: Shells of Xenuroturris / Iotyrris complex. A-C. Iotyrris devoizei. A. MNHN-IM2009-24941, Mozambique, SL 17.1 mm. B. Holotype, MNHN-IM-2000-20014, Vanuatu, SL 17.8 mm. C. MNHN-IM-2013-40058, Marquesas Islands, SL 21.6 mm. D. New Caledonia, Expédition MONTROUZIER, st. 1271, SL 27.9 mm. E-G. Iotyrris kingae. E. MNHN-IM-2009-33554, Philippines, SL 19.9 mm. F. New Caledonia, Expédition MONTROUZIER, st. 1319, SL 17.3 mm. G. Holotype, Bishop Museum, BPBM 9970, SL 15 mm. H. ?Xenuroturris cerithiformis, holotype, USNM 338601, SL 38.5 mm. I. Iotyrris marquesensis, holotype, MNHN-IM-2000-3074, SL $28.8 \mathrm{~mm}$. J. Iotyrris millepunctata, MNHN-IM- 2013-57331, New Caledonia, SL $34.6 \mathrm{~mm}$. A-G - at the same scale. H-J - at the same scale. Scale bars $1 \mathrm{~cm}$. A, B, C, E, J - sequenced specimens. Figure G - courtesy of Bishop Museum, Honolulu, Hawaii, USA. 
949 Supplementary Material 1: Phylogenetic trees obtained with IQ-tree and the RAD-seq data, 950 with 30, 40, 50, 60 and $70 \%$ of missing data. Bootstraps values above 95 are shown for each 951 node. 


\begin{tabular}{|c|c|c|c|c|}
\hline $\mathbf{N}^{\circ} \mathbf{M N H N}$ & Country & Coordinates; Depth & Genus & species \\
\hline MNHN-IM-2007-17686 & Vanuatu & $15^{\circ} 33,6^{\prime} \mathrm{S}, 167^{\circ} 16,6^{\prime} \mathrm{E} ; 8-9 \mathrm{~m}$ & Iotyrris & cingulifera \\
\hline MNHN-IM-2009-17246 & Madagascar & $25^{\circ} 02.6^{\prime} \mathrm{S}, 47^{\circ} 01.2^{\prime} \mathrm{E} ; 45-49 \mathrm{~m}$ & Xenuroturris & legitima \\
\hline MNHN-IM-2009-24927 & Mozambique & $25^{\circ} 59.7^{\prime} \mathrm{S}, 32^{\circ} 54.5^{\prime} \mathrm{E} ;-1 \mathrm{~m}$ & Iotyrris & cingulifera \\
\hline MNHN-IM-2009-24928 & Mozambique & $25^{\circ} 59.0^{\prime} \mathrm{S}, 32^{\circ} 54.3^{\prime} \mathrm{E} ; 3-5 \mathrm{~m}$ & Iotyrris & devoizei \\
\hline MNHN-IM-2009-24929 & Mozambique & 2559.7'S, 3254.5'E; -1m & Iotyrris & cingulifera \\
\hline MNHN-IM-2009-24930 & Mozambique & 2559.7'S, 3254.5'E; 2-5m & Xenuroturris & legitima \\
\hline MNHN-IM-2009-24936 & Mozambique & 2559.7'S, 3254.5'E; 2-5m & Xenuroturris & legitima \\
\hline MNHN-IM-2009-24939 & Mozambique & $26^{\circ} 10.9^{\prime} \mathrm{S}, 32^{\circ} 57.2^{\prime} \mathrm{E} ;-15 \mathrm{~m}$ & Iotyrris & devoizei \\
\hline MNHN-IM-2009-24940 & Mozambique & $25^{\circ} 59.7^{\prime} \mathrm{S}, 32^{\circ} 54.5^{\prime} \mathrm{E} ; 2-5 \mathrm{~m}$ & Xenuroturris & legitima \\
\hline MNHN-IM-2009-24949 & Mozambique & $25^{\circ} 58.6^{\prime} \mathrm{S}, 32^{\circ} 54.1^{\prime} \mathrm{E} ;-15 \mathrm{~m}$ & Iotyrris & devoizei \\
\hline MNHN-IM-2009-24959 & New Caledonia & $23^{\circ} 19^{\prime} \mathrm{S}, 168^{\circ} 16^{\prime} \mathrm{E} ; 180-220 \mathrm{~m}$ & Iotyrris & olangoensis \\
\hline MNHN-IM-2009-24987 & Philippines & $10^{\circ} 17^{\prime} 35 " \mathrm{~S}, 123^{\circ} 55^{\prime} 31^{\prime \prime E} ; 15-25 \mathrm{~m}$ & Iotyrris & olangoensis \\
\hline MNHN-IM-2009-24988 & Philippines & $10^{\circ} 17^{\prime} 35^{\prime \prime S}, 123^{\circ} 55^{\prime} 31^{\prime \prime E} ; 15-25 \mathrm{~m}$ & Iotyrris & olangoensis \\
\hline MNHN-IM-2009-24990 & Philippines & $10^{\circ} 17^{\prime} 35^{\prime \prime S}, 123^{\circ} 55^{\prime} 31^{\prime \prime E} ; 15-25 \mathrm{~m}$ & Iotyrris & olangoensis \\
\hline MNHN-IM-2009-24992 & Philippines & $10^{\circ} 17^{\prime} 35^{\prime \prime S}, 123^{\circ} 55^{\prime} 31^{\prime \prime E} ; 15-25 \mathrm{~m}$ & Iotyrris & olangoensis \\
\hline MNHN-IM-2009-24993 & Philippines & $10^{\circ} 17^{\prime} 35^{\prime \prime S}, 123^{\circ} 55^{\prime} 31^{\prime \prime E} ; 15-25 \mathrm{~m}$ & Xenuroturris & legitima \\
\hline MNHN-IM-2009-24997 & Philippines & $10^{\circ} 17^{\prime} 35^{\prime \prime S}, 123^{\circ} 55^{\prime} 31 " \mathrm{E} ; 15-25 \mathrm{~m}$ & Iotyrris & musivum \\
\hline MNHN-IM-2009-26289 & Vanuatu & $15^{\circ} 36,1^{\prime} \mathrm{S}, 166^{\circ} 58,5^{\prime} \mathrm{E} ; 16 \mathrm{~m}$ & Iotyrris & devoizei \\
\hline MNHN-IM-2009-29709 & Vietnam & $12^{\circ} 10,443^{\prime} \mathrm{N}, 109^{\circ} 16,298^{\prime} \mathrm{E} ; 15-22 \mathrm{~m}$ & Iotyrris & cingulifera \\
\hline MNHN-IM-2009-29714 & Vietnam & $12^{\circ} 10,443^{\prime} \mathrm{N}, 109^{\circ} 16,298^{\prime} \mathrm{E} ; 15-22 \mathrm{~m}$ & Iotyrris & conotaxis n. sp. \\
\hline MNHN-IM-2009-29715 & Vietn & $12^{\circ} 10,443^{\prime} \mathrm{N}, 109^{\circ} 16,298^{\prime} \mathrm{E} ; 15-22 \mathrm{~m}$ & Iotyrris & musivum \\
\hline MNHN-IM-2009-29719 & Vietnam & $12^{\circ} 10,443^{\prime} \mathrm{N}, 109^{\circ} 16,298^{\prime} \mathrm{E} ; 15-22 \mathrm{~m}$ & Xenuroturris & legitima \\
\hline MNHN-IM-2009-29720 & Vie & $12^{\circ} 10,443^{\prime} \mathrm{N}, 109^{\circ} 16,298^{\prime} \mathrm{E} ; 15-22 \mathrm{~m}$ & Iotyrris & notata \\
\hline MNHN-IM-2009-29726 & Vietnam & $12^{\circ} 10,443^{\prime} \mathrm{N}, 109^{\circ} 16,298^{\prime} \mathrm{E} ; 15-22 \mathrm{~m}$ & Iotyrris & notata \\
\hline MNHN-IM-2009-33530 & Philippines & $10^{\circ} 17^{\prime} \mathrm{S}, 123^{\circ} 55^{\prime} \mathrm{E} ; 15-20 \mathrm{~m}$ & Xenuroturris & legitima \\
\hline MNHN-IM-2009-33531 & Philippines & $10^{\circ} 17^{\prime} \mathrm{S}, 123^{\circ} 55^{\prime} \mathrm{E} ; 15-20 \mathrm{~m}$ & Xenuroturris & legitima \\
\hline MNHN-IM-2009-33533 & Philippines & $10^{\circ} 17^{\prime} \mathrm{S}, 123^{\circ} 55^{\prime} \mathrm{E} ; 15-20 \mathrm{~m}$ & Xenuroturris & legitima \\
\hline MNHN-IM-2009-33534 & Philippines & $10^{\circ} 17^{\prime} \mathrm{S}, 123^{\circ} 55^{\prime} \mathrm{E} ; 15-20 \mathrm{~m}$ & Xenuroturris & legitima \\
\hline MNHN-IM-2009-33536 & Philippines & $10^{\circ} 17^{\prime} \mathrm{S}, 123^{\circ} 55^{\prime} \mathrm{E} ; 15-20 \mathrm{~m}$ & Iotyrris & musivum \\
\hline MNHN-IM-2009-33537 & Philippines & $10^{\circ} 17^{\prime} \mathrm{S}, 123^{\circ} 55^{\prime} \mathrm{E} ; 15-20 \mathrm{~m}$ & Iotyrris & musivum \\
\hline MNHN-IM-2009-33538 & Philippines & $10^{\circ} 17^{\prime} \mathrm{S}, 123^{\circ} 55^{\prime} \mathrm{E}$; $15-20 \mathrm{~m}$ & Xenuroturris & legitima \\
\hline MNHN-IM-2009-33539 & Philippines & $10^{\circ} 17^{\prime} \mathrm{S}, 123^{\circ} 55^{\prime} \mathrm{E} ; 15-20 \mathrm{~m}$ & Iotyrris & conotaxis n. sp. \\
\hline MNHN-IM-2009-33540 & Philippines & $10^{\circ} 17^{\prime} \mathrm{S}, 123^{\circ} 55^{\prime} \mathrm{E} ; 15-20 \mathrm{~m}$ & Iotyrris & musivum \\
\hline MNHN-IM-2009-33542 & Philippines & $10^{\circ} 17^{\prime} \mathrm{S}, 123^{\circ} 55^{\prime} \mathrm{E} ; 15-20 \mathrm{~m}$ & Iotyrris & cingulifera \\
\hline MNHN-IM-2009-33544 & Philip & $10^{\circ} 17^{\prime} \mathrm{S}, 123^{\circ} 55^{\prime} \mathrm{E} ; 15-20 \mathrm{~m}$ & Iotyrris & cingulifera \\
\hline MNHN-IM-2009-33545 & Philippines & $10^{\circ} 17^{\prime} \mathrm{S}, 123^{\circ} 55^{\prime} \mathrm{E} ; 15-20 \mathrm{~m}$ & Iotyrris & cingulifera \\
\hline MNHN-IM-2009-33546 & Philippines & $10^{\circ} 17^{\prime} \mathrm{S}, 123^{\circ} 55^{\prime} \mathrm{E} ; 15-20 \mathrm{~m}$ & Iotyrris & musivum \\
\hline MNHN-IM-2009-33548 & Philippines & $10^{\circ} 17^{\prime} \mathrm{S}, 123^{\circ} 55^{\prime} \mathrm{E} ; 15-20 \mathrm{~m}$ & Iotyrris & conotaxis n. $\mathrm{s}$ \\
\hline MNHN-IM-2009-33549 & Philippines & $10^{\circ} 17^{\prime} \mathrm{S}, 123^{\circ} 55^{\prime} \mathrm{E} ; 15-20 \mathrm{~m}$ & Xenuroturris & legitima \\
\hline MNHN-IM-2009-33550 & Philippines & $10^{\circ} 17^{\prime} \mathrm{S}, 123^{\circ} 55^{\prime} \mathrm{E} ; 15-20 \mathrm{~m}$ & Iotyrris & olangoensis \\
\hline MNHN-IM-2009-33553 & Philippines & $10^{\circ} 17^{\prime} \mathrm{S}, 123^{\circ} 55^{\prime} \mathrm{E}$; $15-20 \mathrm{~m}$ & Iotyrris & musivum \\
\hline MNHN-IM-2009-33554 & Philippines & $10^{\circ} 17^{\prime} \mathrm{S}, 123^{\circ} 55^{\prime} \mathrm{E} ; 15-20 \mathrm{~m}$ & Iotyrris & kingae \\
\hline MNHN-IM-2009-33555 & Philippines & $10^{\circ} 17^{\prime} \mathrm{S}, 123^{\circ} 55^{\prime} \mathrm{E} ; 15-20 \mathrm{~m}$ & Xenuroturris & legitima \\
\hline MNHN-IM-2009-33561 & Philippines & $10^{\circ} 17^{\prime} \mathrm{S}, 123^{\circ} 55^{\prime} \mathrm{E} ; 15-20 \mathrm{~m}$ & Iotyrris & olangoensis \\
\hline MNHN-IM-2009-33562 & Philippines & $10^{\circ} 17^{\prime} \mathrm{S}, 123^{\circ} 55^{\prime} \mathrm{E} ; 15-20 \mathrm{~m}$ & Iotyrris & olangoensis \\
\hline MNHN-IM-2009-33563 & Philippines & $10^{\circ} 17^{\prime} \mathrm{S}, 123^{\circ} 55^{\prime} \mathrm{E} ; 15-20 \mathrm{~m}$ & Iotyrris & cingulifera \\
\hline MNHN-IM-2009-33564 & Philippines & $10^{\circ} 17^{\prime} \mathrm{S}, 123^{\circ} 55^{\prime} \mathrm{E} ; 15-20 \mathrm{~m}$ & Iotyrris & conotaxis n. sp. \\
\hline MNHN-IM-2009-33568 & Philippines & $10^{\circ} 17^{\prime} \mathrm{S}, 123^{\circ} 55^{\prime} \mathrm{E} ; 15-20 \mathrm{~m}$ & Iotyrris & musivum \\
\hline MNHN-IM-2009-33569 & Philippines & $10^{\circ} 17^{\prime} \mathrm{S}, 123^{\circ} 55^{\prime} \mathrm{E} ; 15-20 \mathrm{~m}$ & Xenuroturris & legitima \\
\hline MNHN-IM-2009-33570 & Philippines & $10^{\circ} 17^{\prime} \mathrm{S}, 123^{\circ} 55^{\prime} \mathrm{E}$; $15-20 \mathrm{~m}$ & Iotyrris & conotaxis n. sp. \\
\hline MNHN-IM-2009-33572 & Philippines & $10^{\circ} 17^{\prime} \mathrm{S}, 123^{\circ} 55^{\prime} \mathrm{E} ; 15-20 \mathrm{~m}$ & Iotyrris & musivum \\
\hline MNHN-IM-2009-33576 & Philippines & $10^{\circ} 17^{\prime} \mathrm{S}, 123^{\circ} 55^{\prime} \mathrm{E} ; 15-20 \mathrm{~m}$ & Iotyrris & musivum \\
\hline MNHN-IM-2009-33577 & Philippines & $10^{\circ} 17^{\prime} \mathrm{S}, 123^{\circ} 55^{\prime} \mathrm{E} ; 15-20 \mathrm{~m}$ & Iotyrris & musivum \\
\hline MNHN-IM-2009-33578 & Philippines & $10^{\circ} 17^{\prime} \mathrm{S}, 123^{\circ} 55^{\prime} \mathrm{E} ; 15-20 \mathrm{~m}$ & Iotyrris & musivum \\
\hline MNHN-IM-2009-33579 & Philippines & $10^{\circ} 17^{\prime} \mathrm{S}, 123^{\circ} 55^{\prime} \mathrm{E} ; 15-20 \mathrm{~m}$ & Iotyrris & musivum \\
\hline MNHN-IM-2009-6456 & Mozambique & $26^{\circ} 12^{\prime} \mathrm{S}, 35^{\circ} 03^{\prime} \mathrm{E} ; 87-90 \mathrm{~m}$ & Iotyrris & conotaxis n. sp. \\
\hline MNHN-IM-2009-7022 & Mozambique & $25^{\circ} 59.0^{\prime} \mathrm{S}, 32^{\circ} 54.5^{\prime} \mathrm{E}$ & Xenuroturris & legitima \\
\hline MNHN-IM-2009-7023 & Mozambique & $25^{\circ} 59.0^{\prime} \mathrm{S}, 32^{\circ} 54.5^{\prime} \mathrm{E}$ & Iotyrris & cingulifera \\
\hline
\end{tabular}




\begin{tabular}{|l|c|c|c|c|}
\hline MNHN-IM-2009-7024 & Mozambique & $25^{\circ} 59.0^{\prime} \mathrm{S}, 32^{\circ} 54.5^{\prime} \mathrm{E}$ & Iotyrris & cingulifera \\
\hline MNHN-IM-2009-7025 & Mozambique & $25^{\circ} 59.0^{\prime} \mathrm{S}, 32^{\circ} 54.5^{\prime} \mathrm{E}$ & Xenuroturris & legitima \\
\hline MNHN-IM-2009-7081 & Mozambique & $25^{\circ} 59.0^{\prime} \mathrm{S}, 32^{\circ} 54.5^{\prime} \mathrm{E}$ & Xenuroturris & legitima \\
\hline MNHN-IM-2013-14888 & Papua-New-Guinea & $05^{\circ} 11^{\prime} \mathrm{S}, 145^{\circ} 49,5^{\prime} \mathrm{E} ; 2-10 \mathrm{~m}$ & Iotyrris & cingulifera \\
\hline MNHN-IM-2013-40060 & Marquesas Islands & $09^{\circ} 45,67^{\prime} \mathrm{S}, 138^{\circ} 50,69^{\prime} \mathrm{W} ; 10-25 \mathrm{~m}$ & Iotyrris & devoizei \\
\hline MNHN-IM-2013-52076 & Egypt & $26^{\circ} 48^{\prime} 48^{\prime \prime} \mathrm{N}, 33^{\circ} 56^{\prime} 54^{\prime \prime} \mathrm{E} ; 1-2 \mathrm{~m}$ & Iotyrris & cingulifera \\
\hline MNHN-IM-2013-52078 & Egypt & $26^{\circ} 48^{\prime} 48^{\prime \prime} \mathrm{N}, 33^{\circ} 56^{\prime} 54^{\prime \prime} \mathrm{E} ; 1-2 \mathrm{~m}$ & Iotyrris & cingulifera \\
\hline MNHN-IM-2009-29713 & Vietnam & $12^{\circ} 10,443^{\prime} \mathrm{N}, 109^{\circ} 16,298^{\prime} \mathrm{E} ; 15-22 \mathrm{~m}$ & Lophiotoma & jickelii \\
\hline
\end{tabular}




\begin{tabular}{|c|c|c|c|c|c|}
\hline BOLD ID & Genbank \# for COI & Total reads & Reads passed & Total loci & Final loci \\
\hline CONO514-08 & EU127880 & 694199 & 630308 & 3617 & 2311 \\
\hline TEMPO044-18 & MH917863 & 3600990 & 3374050 & 17905 & 12615 \\
\hline TEMPO050-18 & MH917812 & 1293596 & 1223835 & 7515 & 4754 \\
\hline TEMPO051-18 & MH917824 & 3259241 & 3039143 & 14371 & 9983 \\
\hline TEMPO052-18 & MH917809 & 1981423 & 1866477 & 11077 & 7354 \\
\hline TEMPO053-18 & MH917868 & 3740707 & 3504351 & 17562 & 12488 \\
\hline TEMPO054-18 & MH917867 & 2707631 & 2537846 & 15716 & 8064 \\
\hline TEMPO103-18 & MH917821 & 1487639 & 1425098 & 7175 & 4774 \\
\hline TEMPO055-18 & MH917866 & 2115504 & 1999266 & 9503 & 6312 \\
\hline TEMPO056-18 & MH917823 & 2673240 & 2487408 & 11010 & 7162 \\
\hline TEMPO057-18 & MH917843 & 1147331 & 1073660 & 6083 & 3242 \\
\hline TEMPO058-18 & MH917848 & 621317 & 590364 & 3927 & 2687 \\
\hline TEMPO059-18 & MH917842 & 2547012 & 2401207 & 13361 & 9616 \\
\hline TEMPO060-18 & MH917847 & 4790989 & 4454342 & 22688 & 16716 \\
\hline TEMPO061-18 & MH917846 & 2904170 & 2709792 & 15444 & 11259 \\
\hline TEMPO062-18 & MH917864 & 3125200 & 2957616 & 15195 & 10822 \\
\hline TEMPO063-18 & MH917838 & 2007246 & 1895232 & 11599 & 8662 \\
\hline CONO512-08 & EU127879 & 1253969 & 1143822 & 6011 & 3804 \\
\hline TEMPO064-18 & MH917815 & 3884108 & 3659529 & 19469 & 13259 \\
\hline TEMPO065-18 & MH917853 & 616563 & 583635 & 3011 & 1718 \\
\hline TEMPO066-18 & MH917837 & 2800010 & 2680824 & 15992 & 12044 \\
\hline TEMPO067-18 & MH917862 & 1188373 & 1098161 & 4985 & 3181 \\
\hline TEMPO068-18 & MH917840 & 9135778 & 8614984 & 32432 & 21909 \\
\hline TEMPO069-18 & MH917839 & 2968648 & 2785558 & 13687 & 9024 \\
\hline TEMPO070-18 & MH917861 & 1534833 & 1450158 & 8924 & 6261 \\
\hline TEMPO071-18 & MH917860 & 2586377 & 2484120 & 11885 & 8193 \\
\hline TEMPO072-18 & MH917859 & 8601257 & 8172565 & 35030 & 24127 \\
\hline TEMPO073-18 & MH917858 & 2988491 & 2765920 & 13189 & 8959 \\
\hline TEMPO074-18 & MH917826 & 3377363 & 3242368 & 16184 & 12077 \\
\hline TEMPO075-18 & MH917836 & 6041344 & 5631785 & 29218 & 19312 \\
\hline TEMPO076-18 & MH917856 & 5710015 & 5371853 & 25099 & 17868 \\
\hline TEMPO077-18 & MH917849 & 3935930 & 3702928 & 21354 & 15466 \\
\hline TEMPO078-18 & MH917835 & 2165240 & 1989705 & 10988 & 7999 \\
\hline TEMPO079-18 & MH917817 & 2718353 & 2551693 & 12902 & 8822 \\
\hline TEMPO080-18 & MH917820 & 2713372 & 2543124 & 15457 & 11012 \\
\hline TEMPO081-18 & MH917819 & 2260769 & 2101961 & 12753 & 9094 \\
\hline TEMPO082-18 & MH917834 & 2615219 & 2453002 & 13097 & 9545 \\
\hline TEMPO083-18 & MH917852 & 2499420 & 2357567 & 15697 & 11702 \\
\hline TEMPO084-18 & MH917857 & 739942 & 698742 & 3750 & 2132 \\
\hline TEMPO085-18 & MH917841 & 1967315 & 1823804 & 8611 & 5820 \\
\hline TEMPO086-18 & MH917833 & 4597154 & 4372658 & 22254 & 16663 \\
\hline TEMPO087-18 & MH917825 & 5770810 & 5492875 & 26157 & 18567 \\
\hline TEMPO088-18 & MH917865 & 1800651 & 1703896 & 9132 & 6468 \\
\hline TEMPO089-18 & MH917844 & 3110611 & 2931793 & 17218 & 12766 \\
\hline TEMPO090-18 & MH917845 & 4898433 & 4678365 & 22680 & 16345 \\
\hline TEMPO091-18 & MH917814 & 4990679 & 4612622 & 21240 & 14610 \\
\hline TEMPO104-18 & MH917854 & 6835600 & 6491429 & 29470 & 22148 \\
\hline TEMPO092-18 & MH917832 & 3383055 & 3228317 & 18860 & 13367 \\
\hline TEMPO093-18 & MH917869 & 4451716 & 4094310 & 20965 & 14700 \\
\hline TEMPO094-18 & MH917851 & 3232203 & 3038981 & 15976 & 11442 \\
\hline TEMPO095-18 & MH917831 & 4993521 & 4816966 & 23634 & 18023 \\
\hline TEMPO096-18 & MH917830 & 3326764 & 3195354 & 18611 & 13750 \\
\hline TEMPO097-18 & MH917829 & 3392736 & 3076448 & 17071 & 12471 \\
\hline TEMPO098-18 & MH917828 & 2772092 & 2622579 & 15766 & 11940 \\
\hline TEMPO099-18 & MH917827 & 1978175 & 1865570 & 11715 & 8576 \\
\hline TEMPO043-18 & MH917850 & 612170 & 548856 & 1571 & 779 \\
\hline TEMPO045-18 & MH917855 & 6486587 & 6148897 & 33000 & 19236 \\
\hline TEMPO046-18 & MH917813 & 3943003 & 3682059 & 21778 & 12034 \\
\hline
\end{tabular}




\begin{tabular}{|c|c|c|c|c|c|}
\hline TEMPO047-18 & MH917811 & 2651450 & 2500060 & 16263 & 6246 \\
\hline TEMPO048-18 & MH917871 & 8045196 & 7655973 & 40943 & 14177 \\
\hline TEMPO049-18 & MH917870 & 11296176 & 10605392 & 52463 & 19298 \\
\hline TEMPO100-18 & MH917810 & 1841688 & 1720104 & 11264 & 7242 \\
\hline TEMPO101-18 & MH917822 & 9016668 & 8525416 & 33530 & 23998 \\
\hline TEMPO102-18 & MH917818 & 4929978 & 4693937 & 30097 & 16529 \\
\hline TEMPO105-18 & MH917816 & 1894537 & 1730192 & 10657 & 5192 \\
\hline CONO1878-17 & KY570852 & 23237420 & 22117193 & 46894 & 3348 \\
\hline
\end{tabular}




\begin{tabular}{|c|c|c|c|c|c|c|}
\hline \% of missing dat & MinCov & \# loci & \# SNP & $\begin{array}{c}\text { \% nodes with } \\
\text { bootstraps > 75 }\end{array}$ & $\begin{array}{c}\text { \% nodes with } \\
\text { bootstraps > 95 }\end{array}$ & \multicolumn{1}{|c|}{} \\
\hline 30 & 46 & 2 & 22 & 7.93 & 3.17 & 7,93 \\
\hline 40 & 40 & 39 & 251 & 28.57 & 12.7 & 28,57 \\
\hline 50 & 33 & 474 & 3415 & 80.95 & 44.44 & 80,95 \\
\hline 60 & 26 & 2639 & 17248 & 87.30 & 50.79 & 87,30 \\
\hline 70 & 20 & 7013 & 43828 & 92.06 & 61.9 & 92,06 \\
\hline 80 & 13 & 17060 & 97393 & 90.48 & 65.08 & 90,48 \\
\hline
\end{tabular}




\begin{tabular}{|c|}
\hline 3,17 \\
\hline 12,70 \\
\hline 38,01 \\
\hline 50,79 \\
\hline 61,90 \\
\hline 65,08 \\
\hline
\end{tabular}

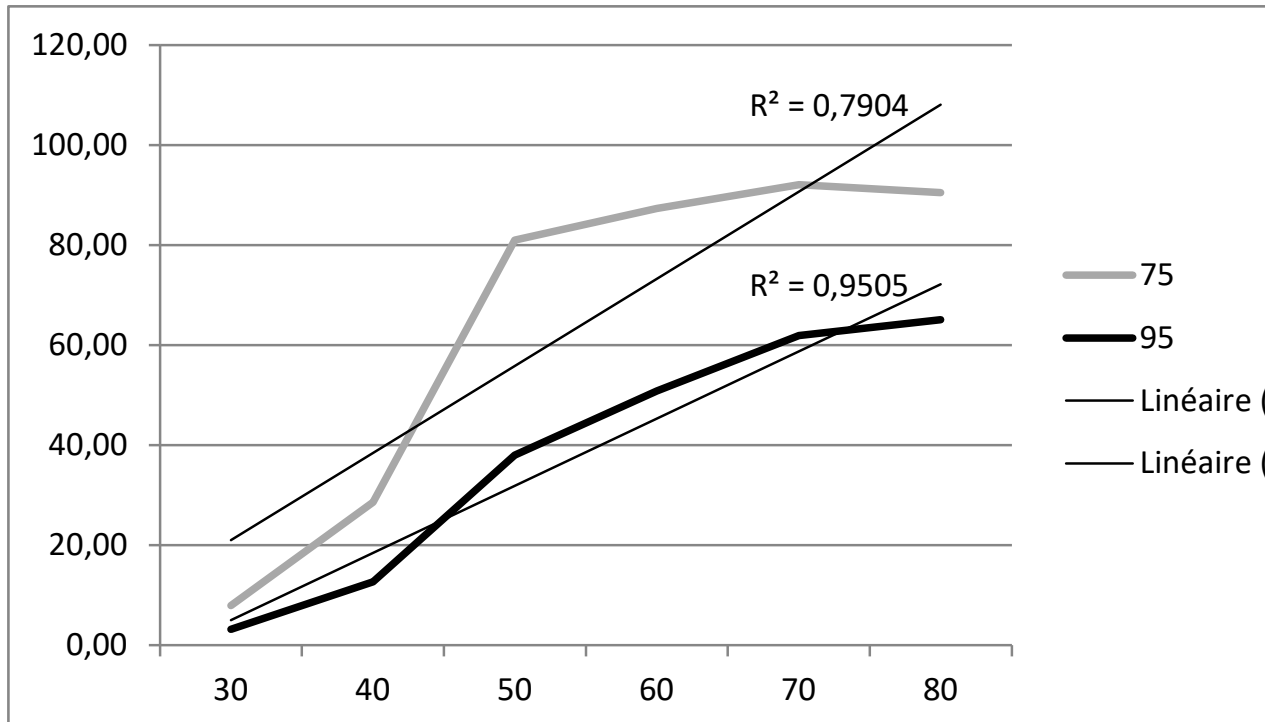


(75)

(95) 


\begin{tabular}{|l|c|c|c|c|}
\hline Species & Number of species considered & Number of steps & Chain lenght & MLE \\
\hline lotyrris cingulifera & 1 & 20 & 100000 & 1188 \\
\hline lotyrris cingulifera & 1 & 50 & 100000 & 889 \\
\hline Iotyrris cingulifera & 1 & 100 & 100000 & 559 \\
\hline lotyrris cingulifera & 1 & 200 & 100000 & 771 \\
\hline lotyrris cingulifera & 1 & 200 & 500000 & 1038 \\
\hline lotyrris cingulifera & 2 & 20 & 100000 & 1336 \\
\hline Iotyrris cingulifera & 2 & 50 & 100000 & infinity \\
\hline lotyrris cingulifera & 2 & 100 & 100000 & 1334 \\
\hline lotyrris cingulifera & 2 & 200 & 100000 & infinity \\
\hline Xenuroturris legitima & 1 & 20 & 100000 & 1142 \\
\hline Xenuroturris legitima & 1 & 50 & 100000 & 1109 \\
\hline Xenuroturris legitima & 1 & 100 & 100000 & 867 \\
\hline Xenuroturris legitima & 1 & 200 & 100000 & 535 \\
\hline Xenuroturris legitima & 1 & 200 & 500000 & 238 \\
\hline Xenuroturris legitima & 2 & 20 & 100000 & 1498 \\
\hline Xenuroturris legitima & 2 & 50 & 100000 & 1497 \\
\hline Xenuroturris legitima & 2 & 100 & 100000 & 1402 \\
\hline Xenuroturris legitima & 2 & 200 & 100000 & 1330 \\
\hline
\end{tabular}




\begin{tabular}{|c|c|c|c|c|}
\hline Characters/species & X. legitima & I. cingulifera & I. notata & I. kingae \\
\hline Subsutural ramp sculpture & 3-5 subequal cords & 3-5 subequal cords & $\begin{array}{l}3 \text { cords, central } \\
\text { most prominent }\end{array}$ & $\begin{array}{l}3 \text { bulging cords, } \\
\text { central very } \\
\text { prominent }\end{array}$ \\
\hline Subsutural ramp colouration & $\begin{array}{l}\text { background colour } \\
\text { with speckles on } \\
\text { cords }\end{array}$ & $\begin{array}{l}\text { background colour } \\
\text { with speckles on } \\
\text { cords }\end{array}$ & $\begin{array}{l}\text { background colour } \\
\text { with speckles on } \\
\text { cords }\end{array}$ & $\begin{array}{l}\text { large subrectangular } \\
\text { brown spots }\end{array}$ \\
\hline $\begin{array}{l}\text { Sinus (=peripheral) cords } \\
\text { morphology }\end{array}$ & $\begin{array}{l}\text { paired subequal, } \\
\text { upper and lower ones } \\
\text { subdivided in two in } \\
\text { large specimens }\end{array}$ & $\begin{array}{l}\text { paired subequal, } \\
\text { only upper one } \\
\text { subdivided in two in } \\
\text { large specimens }\end{array}$ & $\begin{array}{l}\text { paired subequal, } \\
\text { sharp on top , not } \\
\text { subdivided }\end{array}$ & $\begin{array}{l}\text { paired subequal } \\
\text { rather weak }\end{array}$ \\
\hline $\begin{array}{l}\text { Sinus (=peripheral) cords } \\
\text { colouration }\end{array}$ & $\begin{array}{l}\text { large subrectangular } \\
\text { brown spots and } \\
\text { speckles on cords }\end{array}$ & $\begin{array}{l}\text { large subrectangular } \\
\text { brown spots and } \\
\text { very few speckles on } \\
\text { cords (usually } \\
\text { absent) }\end{array}$ & $\begin{array}{l}\text { large speckles on } \\
\text { cords }\end{array}$ & $\begin{array}{l}\text { large aligned } \\
\text { speckles on cords }\end{array}$ \\
\hline Radular central formation & $\begin{array}{l}\text { spear-head shaped } \\
\text { central cusp }\end{array}$ & absent & absent & $\begin{array}{l}\text { short blunt central } \\
\text { cusp and indistinct } \\
\text { lateral flaps }\end{array}$ \\
\hline Radular marginal teeth & duplex & semienrolled & duplex & duplex \\
\hline
\end{tabular}




\begin{tabular}{l|l|l|l|}
\hline \multicolumn{1}{c|}{ I. devoizei } & \multicolumn{1}{|c|}{ I. olangoensis } & \multicolumn{1}{c|}{ I. musivum } & \multicolumn{1}{c|}{ I. conotaxi } \\
\hline $\begin{array}{l}\text { 3 bulging cords, } \\
\text { central very } \\
\text { prominent, rarely 2 } \\
\text { cords }\end{array}$ & $\begin{array}{l}\text { 3 cords, central most } \\
\text { prominent }\end{array}$ & $\begin{array}{l}\text { 3 cords, central } \\
\text { most prominent }\end{array}$ & $\begin{array}{l}\text { 3 cords, central most } \\
\text { prominent }\end{array}$ \\
\hline $\begin{array}{l}\text { large } \\
\text { subrectangular } \\
\text { brown spots }\end{array}$ & $\begin{array}{l}\text { large subrectangular } \\
\text { brown spots }\end{array}$ & $\begin{array}{l}\text { background colour } \\
\text { with speckles on } \\
\text { cords }\end{array}$ & $\begin{array}{l}\text { speckles on cords, } \\
\text { strong to weak brown } \\
\text { spots }\end{array}$ \\
\hline $\begin{array}{l}\text { paired subequal } \\
\text { rather weak }\end{array}$ & $\begin{array}{l}\text { paired subequal rather } \\
\text { weak, upper can be } \\
\text { subdivided }\end{array}$ & $\begin{array}{l}\text { paired subequal, } \\
\text { prominent, upper } \\
\text { can be subdivided }\end{array}$ & $\begin{array}{l}\text { paired subequal, } \\
\text { prominent, upper can } \\
\text { be subdivided }\end{array}$ \\
\hline $\begin{array}{l}\text { large aligned } \\
\text { speckles on cords }\end{array}$ & speckles on cords & $\begin{array}{l}\text { large } \\
\text { subrectangular } \\
\text { brown spots }\end{array}$ & $\begin{array}{l}\text { large subrectangular } \\
\text { brown spots }\end{array}$ \\
\hline $\begin{array}{l}\text { lateral flaps and } \\
\text { small central cusp }\end{array}$ & narrow central cusp & $\begin{array}{l}\text { sometimes } \\
\text { semienrolled } \\
\text { flaps }\end{array}$ & semienrolled \\
\hline
\end{tabular}




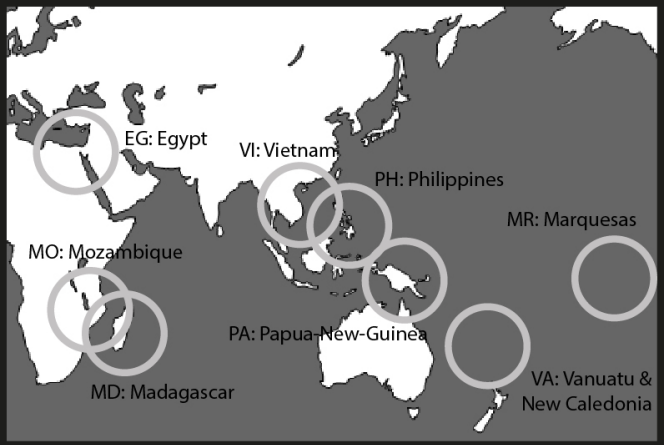




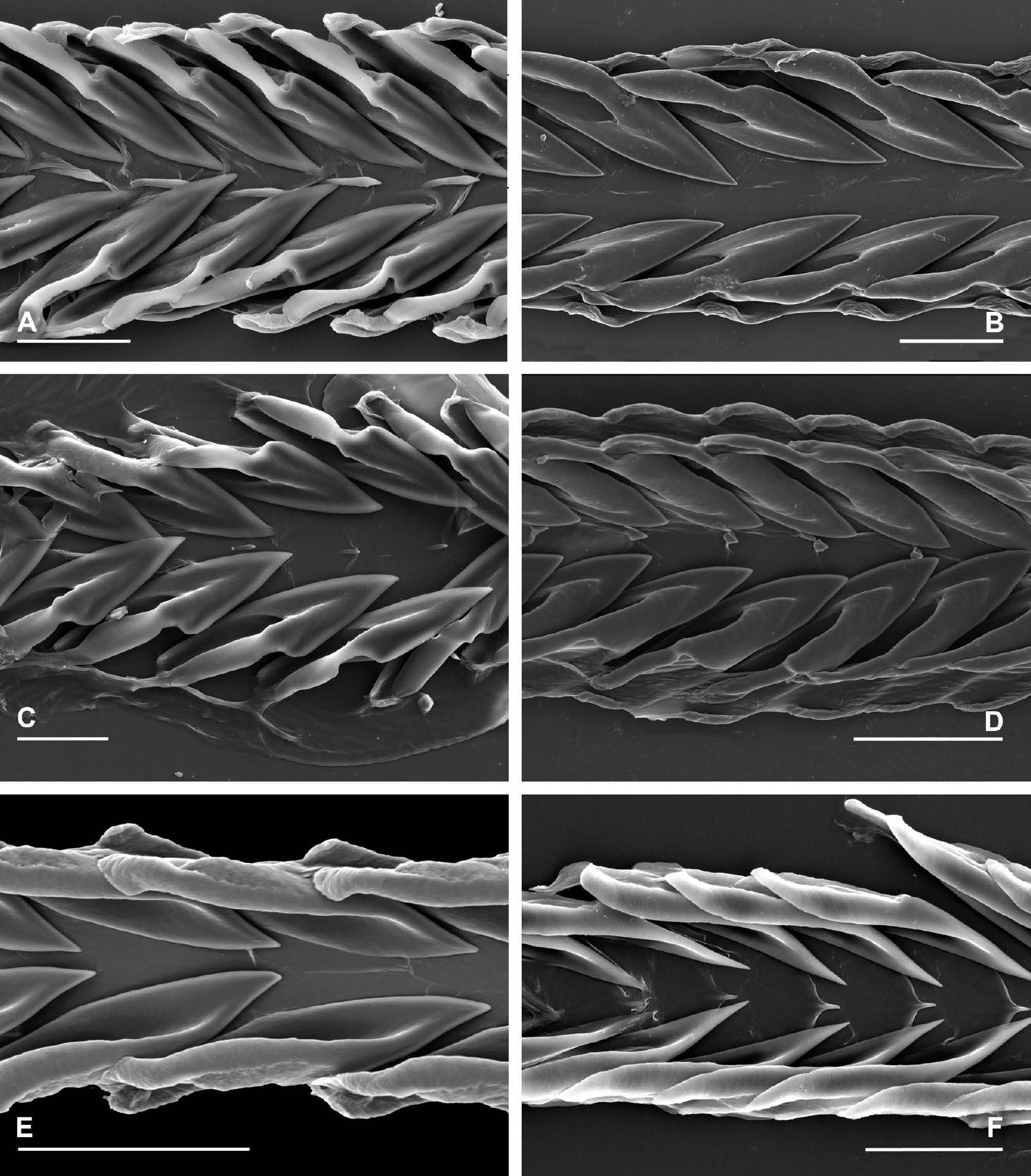




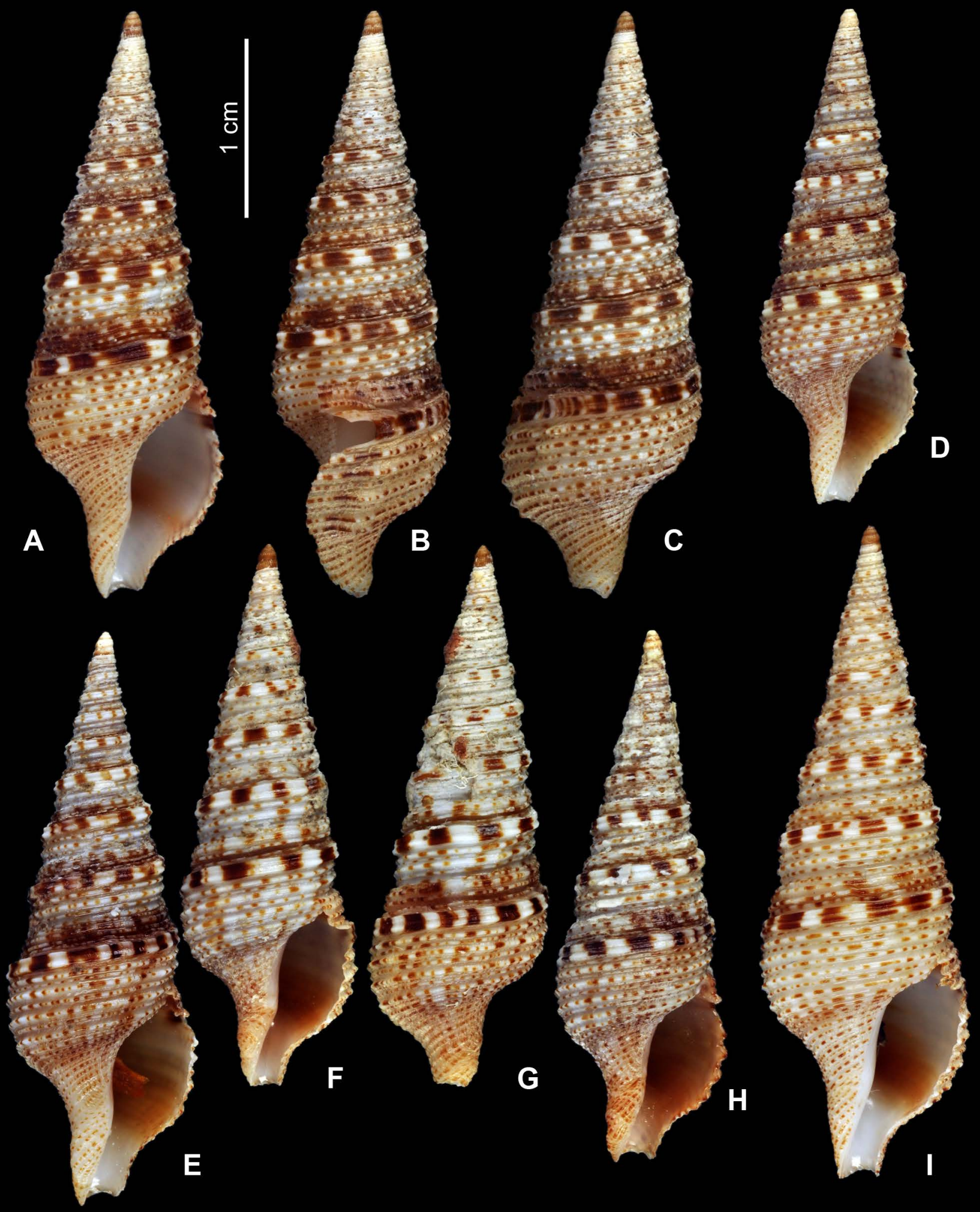




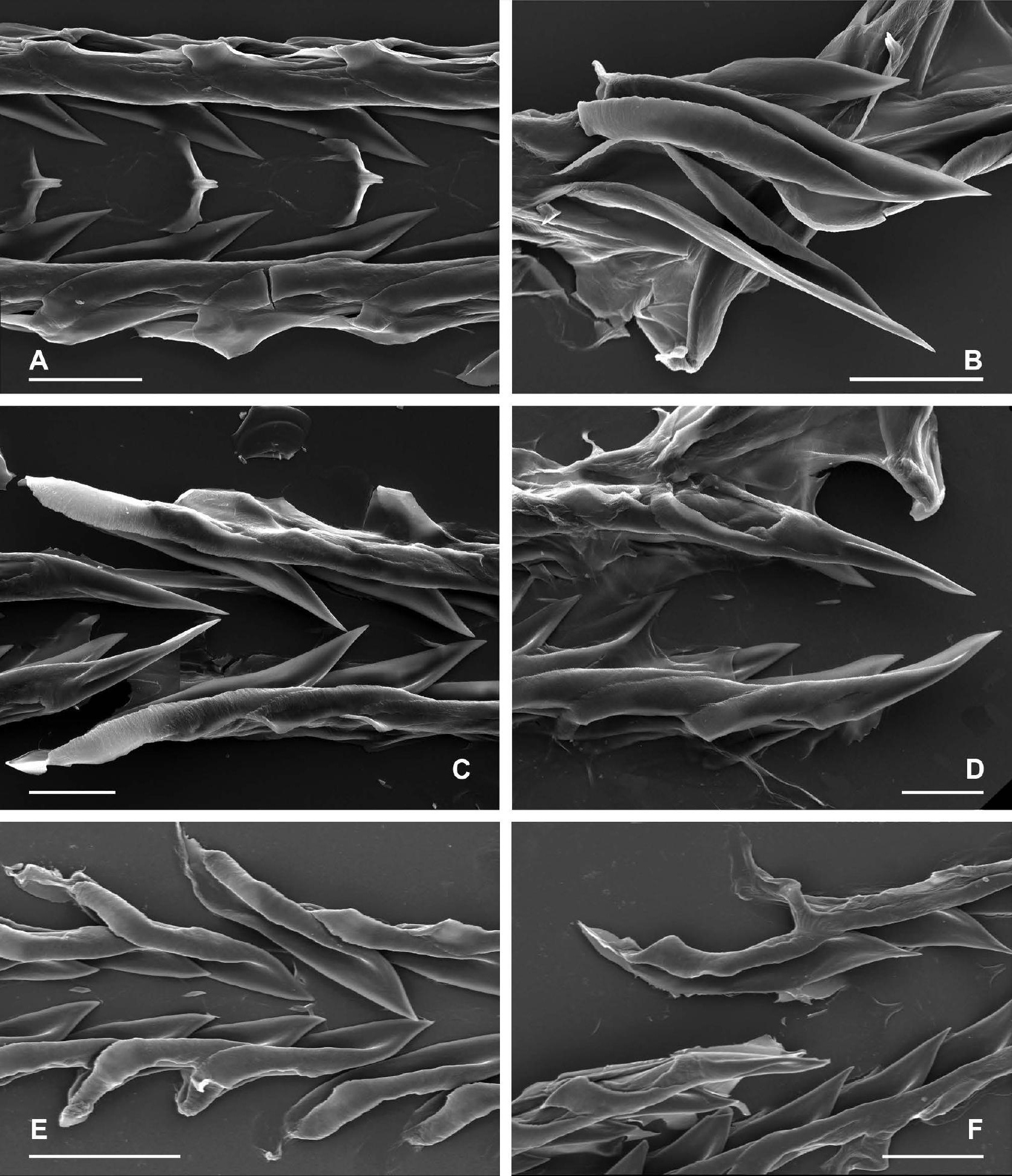




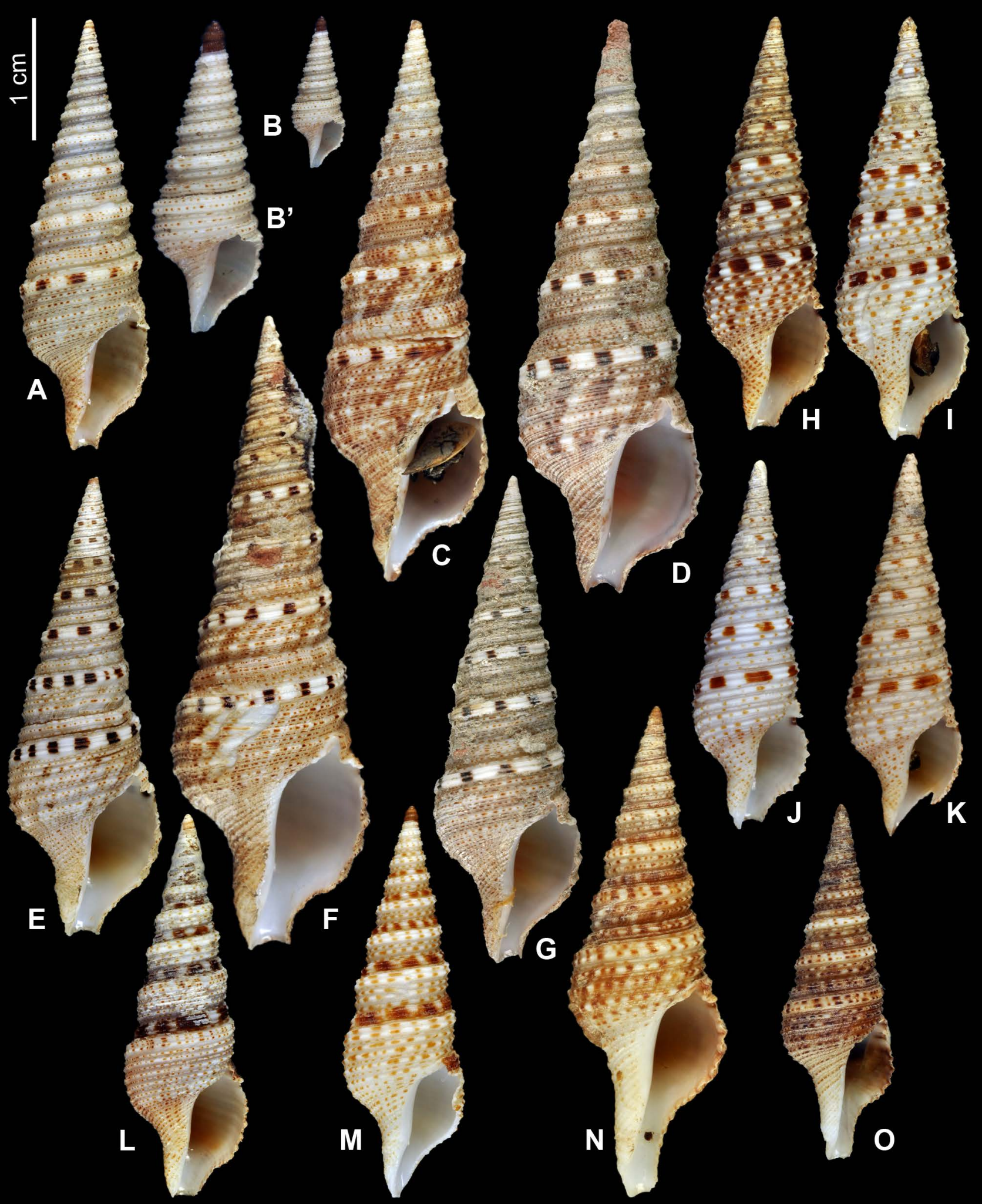


